\title{
Pintor de almas en la moderna Babilonia. Tardosimbolismo y déco en la pintura de Federico Beltrán
}

\author{
Manuel Mujeriego Botella *
}

\begin{abstract}
RESUMEN
ABSTRACT

El propósito del presente artículo es realizar una introducción a la obra pictórica del artista hispano-cubano

Federico Beltrán. Nadie como él representa la transición entre la estética simbolista española de principios del siglo xx y el primer estilo decó que se gesta a finales de los años diez, como queda reflejado en el propio título del mismo: Pintor de Almas en la Moderna

Babilonia. Significamos además su amistad con los «escritores eróticos" José Francés o Antonio de Hoyos y

Vinent, como punto de partida del núcleo referencial de su obra, marcada por un simbolismo decadente, inspirado

por la tradición centroeuropea $y^{\prime}$ anglosajona, $y$ aderezada con abundantes tópicos de españolidad.

The aim of the following article is to provide an introduction about the works of Cuban painter Federico Beltrán. He may well represent a model in the transition between the symbolist painting tradition within the Spanish Art in the early $20^{\text {th }}$ century towards the déco style which was later developed in the 1910's and 1920's. This model is referred to in the title itself, i.e.: Painter of Souls in the Modern Babilon. Since he befriended "erotic writers» José Francés and Antonio de Hoyos y Vinent, his style tended towards a decadent symbolism of central european and anglosaxon inspiration, presenting neverthelees abundant features of Spanish identity.
\end{abstract}

Tras las últimas revisiones del 98 llevadas a cabo con motivo de su centenario y, por ende, del fin de siglo intelectual y artístico en general, parece irrefutable la existencia de una estética simbolista en nuestro país que se manifiesta durante los últimos años del siglo XIX y las primeras décadas del $x x$. Lo que en otras naciones adquiere casi siempre un aspecto

* Tercer Ciclo. Departamento de Historia del Arte. UNED. 
escapista, se observa aquí como una reacción de modernidad que reúne posturas como el prerrafaelismo, el esteticismo, el postimpresionismo, el art nouveau..., con un sentido casi siempre iconoclasta pero incontestable. Dicha estética, influida por las corrientes europeas del momento a través de diferentes vías: viajes a París, Bruselas, Viena o Londres; contactos con artistas como Peladan o Verhaeren..., tiene además en España un carácter regenerador de la inteligencia finisecular, en un marco político y social agotado.

Este aspecto renovador - que no rupturista - a medio camino entre academia y vanguardia debe vincularse al pensamiento y la literatura de una burguesía inconformista, que expresa a través del arte sus deseos de modernidad con amplias dosis de esnobismo. Sus claves ideológicas implican posturas como el dandismo o la decadencia, actitudes misteriosas - espirituales, y a intelectuales tan variados como Walter Pater, Oscar Wilde, Baudelaire, Huysmans o Rubén Darío, conviviendo y a veces amparadas por la nueva españolidad noventayochista. Así, por ejemplo, Unamuno defenderá elogiosamente la regresión prerrafaelita y especialmente la actividad de William Morris, es bien conocida la relación de ValleInclán con lo simbólico y su admiración por Boticelli y los nacionales Romero de Torres o Anselmo Miguel Nieto, y no debemos olvidar el impacto que en los Machado suscitó la exposición parisina de 1900.

El clima de exaltación y contradicciones históricas, filosóficas y estéticas que describimos favoreció la proliferación en España de estas tendencias introspectivas, coincidiendo con la crisis del orden que había propuesto el krausismo. La recepción de lo simbólico se hará a través de las vias tradicionales: ideológica y alegórica, que se funden además con las grandes corrientes de opinión nacionales como el tradicionalismo y el regionalismo, y derivan en una propuesta ecléctica de carácter hispano, en la que se mezclan elementos de expresión esteticistas con un ideario entresacado del decadentismo francés y el misticismo centroeuropeo, y aderezado con los tópicos de la España más recalcitrante. El simbolismo español, así entendido, resultaría un cajón de sastre que incluiría al círculo catalán de Rusiñol y Riquier, a los artistas del Nuevo Café de Levante y a pintores tan cercanos al europeismo alegórico como Rogelio de Egusquiza, Anglada Camarasa e incluso el Zuloaga más próximo a El Greco.

Por ello, en la transición al nuevo siglo y durante los primeros años del mismo no es extraño - aunque no siempre bien aceptado- encontrar en nuestro país un tipo de pintura definido por lo conceptual, por el individualismo de sus autores, por unos rasgos formales heredados del pesimismo 
antipositivista, por el anhelo de la belleza ideal y por una temática que se mueve entre el clasicismo mitológico, el misterio y la fantasía medieval y renacentista, y el mundo del ensueño y la religión. A pesar de esto, nunca existió en España un movimiento integrado y definido como tal, pero tampoco lo hubo en Europa con la sola excepción de los salones rosacrucianos. No debemos olvidar que la entrada del nuevo siglo comportó un cambio de actitud en los criterios pictóricos de muchos de nuestros artistas y que dicho cambio con frecuencia fue efímero y motivado por las más variadas razones. En ocasiones, respondía a un deseo consciente de renovación y estaba amparado por una intelectualidad bohemia, en otras, las más, resultó ser un simple modismo de temporada que confundía el fondo con la técnica, la idea con el color, y era capaz de apuntarse a la vez a dos corrientes surgidas de una antítesis. Es un hecho, además, que las Exposiciones Nacionales - a pesar de su tradicional espíritu retardatoriosirvieron de escaparate a esta nueva moda y que, con la excepción de los más cosmopolitas o los rara avis, todos los artistas buscaron en los salones madrileños el reconocimiento a su obra, pero muchos de ellos también a su modernidad.

La progresión de este cambio se constata, como ha señalado Pérez Rojas ${ }^{1}$, en la Exposición de 1904, cuando se generalizan los premios a los pintores de esta corriente simbólico-modernista: Eduardo Chicharro, Manuel Benedito o Fernando Álvarez de Sotomayor. La crítica pictórica de la época se refiere a ellos dentro de esa línea estética considerada poética y decorativa, y son definidos de forma elogiosa en su búsqueda de los ideales clásicos de la "alta pintura», inspirados en la literatura grecorromana, renacentista y barroca ${ }^{2}$. La generalización de este tipo de temas contribuyó a dotar de cierta uniformidad a un grupo de por sí bastante disperso; al mismo tiempo introducía ese rasgo de internacionalidad que justifica su expansión durante los inicios del siglo. El aperturismo posibilitó también la proliferación de otras corrientes simbolistas menos académicas, derivadas de distintas influencias personales. A este respecto, las Exposiciones de 1904 y 1906 -primera a la que concurre Beltrán, con una obra no simbolista- sirvieron también de escaparate al neomisticismo de Brull o Todá, y a la fantasía introspectiva de Xiró, inspirada por Khnopff.

\footnotetext{
1 Pérez Rojas, J. y García Castellón, M. El siglo xx. Persistencias y rupturas. Madrid. Sílex. 1994. Págs. 40-44.

2 Chicharro había concurrido a la exposición con el tríptico El Poema de Armida y Rinaldo, basado en la Jerusalén Libertada de Tasso; Benedito con una obra inspirada en la Divina Comedia de Dante; y Álvarez de Sotomayor con Orfeo perseguido por las bacantes, extraído de la Metamorfosis de Ovidio.
} 
El futuro de esta nueva generación de pintores (y del arte que representaban) motivó la disensión de la crítica entre sus partidarios, que desde las páginas de El Liberal veían en ella una esperanza de rejuvenecimiento, y sus detractores, como el crítico de El Globo, para quien constituían meros imitadores del arte centroeuropeo.

Lola Caparrós, en sus diferentes trabajos sobre el simbolismo en las Exposiciones Nacionales, ha significado la realizada en 1908 como "la expansión de la corriente simbolista" ${ }^{3}$. Quizá, y en referencia a lo comentado con anterioridad, podríamos hablar incluso de culminación del movimiento en su sentido más clásico. Lo cierto es que hasta esa fecha el simbolismo pictórico en nuestro país estaba avalado por una corriente innovadora procedente del exterior y el deseo individual de renovación de los jóvenes artistas. Pero 1908, al menos en lo que a la muestra se refiere, había consagrado popularmente - que no ante el jurado- al pintor simbolista por excelencia: Julio Romero de Torres, había dado a conocer el misterio del arte teorizado por Valle-Inclán y, sobre todo, había levantado para siempre la barrera entre los naturalistas y los arcaizantes, entre la tradición y la renovación. El primer premio en la sección de artes decorativas concedido a Eulogio Varela - dibujante de Blanco y Negro- refrenda el reconocimiento explícito a ese simbolismo populista, más o menos teñido de nouveau, que era común desde principios del siglo en revistas barcelonesas y madrileñas como Almanach de L'Esquella de la Torratxa, Luz, Álbum Salón, Pel \& Ploma, La Vida Literaria, Arte Joven o el citado Blanco y Negro. Además, a partir de este momento surgirán nuevas líneas de experimentación pictórica en la profundización de los temas simbólicos, del regionalismo y del clasicismo mediterráneo noucentista, o se impondrá la emigración a París.

Este último comentario puede darnos una idea de la confluencia de gustos y estilos que devienen en nuestro simbolismo y derivan de él. Es fiel reflejo de la dificultad para acotarlo en torno a un referente común - «la primera característica del simbolismo español es su inconcreción», ha señalado Calvo Serraller ${ }^{4}$-, pero reafirma también su presencia consolidada en nuestro país al final de la primera década del siglo xx y un

3 Caparrós Masegosa, L. « ¿Clásicos o modernos? El Renacimiento como coordenada estética de la pintura simbolista española". En Actas del X Congreso del CEHA. UNED. Madrid. 1994. Pág. 132. Y «Apuntes para un catálogo de pintura simbolista en las Exposiciones Nacionales de Bellas Artes (1901-1908)». Rev. Goya n. ${ }^{\circ}$ 253-254. Madrid. 1996. Págs. 40-49.

4 Calvo Serraller, F. «El símbolo y su influencia en la pintura española del fin de siglo (18901930)". En catálogo de exposición: Pintura simbolista española (1890-1930). Madrid. Fundación Mapfre Vida. 1997. Págs.46-48. 
Pintor de almas en la moderna Babilonia. Tardosimbolismo y déco en la pintura...

substrato ideológico amplísimo, resumido en esta cita de Valle-Inclán a propósito de la citada Exposición de 1908: "Yo suelo expresar en una frase este concepto estético que conviene por igual a la pintura y a la literatura: Nada es como es, sino como se recuerda" ${ }^{5}$.

Al no existir una postura homogénea premeditada, ni siquiera corporativa, los límites cronológicos del simbolismo español deben buscarse en las demandas del mercado artístico o en los gustos personales de cada pintor. Algunos de ellos, para aumentar la controversia, titubearán entre varios géneros volviendo a realizar obras simbolistas en fechas muy avanzadas. Pero durante los primeros años diez continuaron casi inamovibles los mismos esquemas estéticos que se habían forjado en la década precedente. El simbolismo seguía siendo acusado por arcaico y negro, o defendido por lo mismo, renacentista e inquieto, según el grado de modernidad del crítico de turno. Resulta interesante observar en el siguiente texto de Gabriel García Maroto sobre las obras de Romero de Torres presentadas a la Nacional de 1912 esa diferencia de opiniones y la admisión de la postura simbólica, al menos la más comprensible, por parte de la generalidad del público: «Entre las obras que atraían la atención de los visitantes, originando discusiones acaloradas, las de Julio Romero de Torres eran sin duda las primeras; vejado en la Exposición anterior por un Jurado sin razón o sin conciencia artística y elevado por la prensa al más alto grado de desagravio a la obra inferida, el público, el público ingenuo y sin prejuicio estaba de su parte...» 6 .

Durante los años que distan entre las Exposiciones Nacionales referidas (1908-1912) se estaba gestando en España un cambio político en el régimen canovista que influyó en el mundo de la cultura y el arte. José Carlos Mainer lo ha resumido como la desaparición del «modernismo más combativo, vinculado a la bohemia como actitud insurgente y a la imaginación más desatada como arma de combate" y la aparición de un nuevo espíritu creativo que busca «la revisión emotiva del pasado y el compromiso moral con el presente " ${ }^{7}$. El referente artístico ya no podía ser la regeneración, sino una calma en forma de clasicismo hispano, teñido de tópicos regionales o de azul mediterráneo, que conviviría con un modernismo en crisis, cada vez más cosmopolita y menos beligerante.

\footnotetext{
5 VAlle-IncLÁn, R. Artículos completos y otras páginas olvidadas. Ed. Javier Serrano. Madrid. Istmo. 1987. Pág. 207.

6 García Maroto, G. El año artístico. Relación de sucesos acaecidos al arte español en 1912. Madrid. Fernández Arias. 1913. Pág. 32.

7 MAINER, J.C. «La invención estética de las periferias". En catálogo de exposición: Centro y periferia en la modernización de la pintura española, 1880-1918. Barcelona. Ministerio de Cultura. 1993. Págs. 32-33.
} 
Francesc Fontbona habla de este simbolismo tardío en relación con dicha corriente nacional, no catalana, en la que pervive un «arte literario, irrealista y decadente... específicamente hispano, aunque hay que relacionarlo de alguna manera con la estética que en el mundo occidental gravitaba en torno al escritor Gabriele D'Annunzio", que tendría sus nombres propios en Romero de Torres y Viladrich, y su referente intelectual en Valle-Inclán ${ }^{8}$. Si nos atenemos a esta cita, si el tardosimbolismo es la influencia del pensamiento del poeta italiano sobre nuestra pintura, lo sería también el lujo, el refinamiento y la sensualidad —no exenta de cierto nihilismo amanerado- de las obras de Hermen Anglada Camarasa, José María Sert, Néstor Martín Fernández de la Torre y, especialmente, Federico Beltrán.

Son estos algunos de los rasgos que definen el último simbolismo. Una nueva estética más acorde con los tiempos, cuyos orígenes habría que buscar en el agotamiento del nouveau, y que recoge las inquietudes de un mundo cada vez más globalizado, presidido por el gusto irracional por la elegancia y lo exótico, que tiene sus imágenes en la moda y en la revisión del personaje del dandi. Es el arte de una sociedad que el dibujante y escultor Ismael Smith en carta a Néstor define «del ajenjo Pernod, el automóvil a $150 \mathrm{~km}$ por hora (sic), el amor superficial, fortísimo pero pasajero, los cigarrillos de opio, la inyección de morfina, trabajando deprisa y mucho, comiendo poco, durmiendo delirando, sufriendo nuestra alma de emociones fuertes, nuestro cuerpo sensaciones extrañas, algo misteriosas... y en fin, la vida de este alma de siglo en la moderna Babilonia» 9 .

En España el tardosimbolismo se funde también con el primer déco, favorecido por la neutralidad en la guerra del catorce y tamizado por rasgos nacionales que perviven del regionalismo renovado y le otorgan un indudable casticismo. Reproduce la cultura del mito y la farándula, la de majas y toreros cantados por Manuel Machado y transportados a idílicos escenarios salidos del revival de lejanas civilizaciones o de los ballets rusos de Diaghilev o Bakst. Tórtola Valencia es la encarnación a la española de la mujer moderna, desinhibida y liberal - «representa el renacimiento del culto a la belleza en la literatura y en el arte de hoy", según el poeta Goy de Silva ${ }^{10}$ - y Anselmo Miguel Nieto o Beltrán serán sus retratistas. Estos personajes, hasta ahora inaccesibles, llegan al gran público a través del

8 Fontbona, F. «La pintura modernista en España». En Hofstätter, H.H. Historia de la pintura modernista en europea. Barcelona. Blume. 1981. Págs. 270-274.

9 Cfr. VILLENA, L.A. “Fin de siglo: visión y terminología». Rev. Barcarola n, 37-38. Albacete. Ayuntamiento. 1991. Pág. 172.

10 En un artículo a propósito de la artista publicado en La Esfera de 1 de julio de 1916. 
cine o de las revistas ilustradas que, gracias a las mejoras reprográficas, experimentan un avance espectacular. Blanco y Negro, España, pero sobre todas, La Esfera (editada por primera vez en 1914) se convierten en los órganos de expresión de la nueva sociedad. Penagos y Silvio Lago -seudónimo con que firma sus críticas de arte el escritor José Francés, extraído del personaje principal de La Quimera de Pardo Bazán- serán sus interlocutores. Enlazando con el gusto simbolista más evidente, los primeros artículos de éste son para alabar a Moreau y Beardsley, y para demostrar sus conocimientos sobre Walter Crane, Burne-Jones o William Morris; después vendrán los elogios hacia Anglada y su generación.

José Francés supone la relación literaria entre la tradición modernistasimbolista finisecular y el espíritu déco, basada en la nueva interpretación de los valores estéticos de Poe, Prévost o Pierre Louys - traducido por él- y en la lectura de su lado más frívolo. Y con Francés una nueva literatura "galante y erótica" de base naturalista, cuyos autores, los Zamacois, Trigo, Mata, Insúa, Belda, López de Haro, El Caballero Audaz... y, sobre todos, Antonio de Hoyos y Vinent, reflejan en sus obras la nueva sociedad lúdica y nocturna que saluda la felicidad del desarrollo industrial urbano y la lujuria desenfrenada de sus bajos fondos, y que representan los dibujantes de El Cuento Semanal, Los Contemporáneos o La Novela Corta y los óleos de Beltrán. Después triunfará el lado amable, el del deporte, el futurismo, la linealidad y el neocubismo; el de Gómez de la Serna que, próximo a la vanguardia, se impondrá en los años veinte como reflejan las ilustraciones de La Novela Semanal, La Novela de Hoy o La Novela Mundial, cuando aquel haya iniciado su etapa parisina más criticable.

Se suceden, complementan y confrontan el esteticismo de Valle-Inclán y el de Gómez de la Serna, el modernismo, el simbolismo y el déco. Y, en medio, las soluciones nacionalistas representadas por Ortega y Zuloaga, la exaltación del regionalismo militante y la vanguardia. Este escenario, complejo y rico a la vez para la creación, sentará las bases de buena parte del arte español contemporáneo. En él se gesta la personalidad pictórica de Federico Beltrán, cosmopolita y mundano, voluptuoso y costumbrista.

\section{BILITIS BEBE PERNOD O EL EPILLOGO SIMBOLISTA}

Federico Armando Beltrán Massés ${ }^{11}$ había nacido en Güira de Melena (Cuba) el 29 de septiembre de 1885 y estudiado en la Llotja barcelonesa

\footnotetext{
11 En algunos textos de época escritos por personas tan próximas al autor como García Maroto, es reseñado con el segundo apellido Masses — sin tilde-, su discípulo Santiago Ontañón
} 
durante los primeros años del nuevo siglo. Esta primera etapa de su pintura transcurrió entre el academicismo pompier aprendido en las aulas con Antonio Caba y un crudo naturalismo autodidacta - con temática del Liébana - inspirado en la «España Negra» de Zuloaga, Salaverría y los Zubiarre. En 1909 acude a la Exposición de Munich y un año más tarde a la de Bruselas, donde entra en contacto con las corrientes simbolistas, conoce a Albert Rousseau y la pintura de Whistler. Nuevas exhibiciones en Buenos Aires, París y Londres se traducen en un primer cambio que tiene su reflejo en la Nacional de 1912, a la que había presentado obras «llenas de simpatía espiritual», de una elegancia, refinamiento y sensualidad en la línea y pureza de color que, según García Maroto, evocaban a delicados y sutiles artistas franceses como La Gandara o Blache y una fuente de inspiración que se remontaba a Dante y Petrarca ${ }^{12}$. Para quien luego sería abanderado de la crítica de vanguardia española, Beltrán era entonces un joven prometedor al que los jurados no solían tener en consideración y uno de los pocos que podía salvarse en la mencionada exposición.

Dos años más tarde, el propio Maroto —su futuro cuñado político-publicaba Teoría de las Artes Nobles. Sin conectar todavía con la vanguardia más evidente, elogiaba la inquietud de los «artistas rebeldes», de aquellos que rompían con los moldes impuestos por la oficialidad más estricta; la referencia estaba dedicada especialmente a Zuloaga, pero aludía asimismo a los pintores esteticistas y los herederos del modernismo: Anglada, Eugenio Hermoso, Romero de Torres, López Mezquita y Federico Beltrán, y al escultor Julio Antonio. También en 1914 habian aparecido las primeras composiciones nocturnas de Beltrán: Noche Azul o Noche Galante (figuras 1 y 2), que inauguraban una serie de cuadros de inspiración hedonista, recreación de fastos bizantinos y donde predominaba el color simbólico por excelencia, el azul ${ }^{13}$, y la decadente negritud de Lorrain o

\footnotetext{
se refiere a él como Masés y otros autores como José Francés o González Ruano escriben indistintamente Masses o Massés, lo que ha dado lugar a citas en diferentes sentidos en la bibliografía actual. En la partida de bautismo extendida en Güira de Melena, Cuba, el 6 de febrero de 1886 por el presbítero D. Rafael Tomil (copiada en 1905 por D. Enrique Ortíz) figura con el nombre completo de «FEDERICO BELTRÁN MASSÉS hijo de D. Luis Beltrán y Fernández y Dña. M.ª de las Mercedes Massés y Estrada, naturales de Madrid». Archivo parroquial de Guira. Primer libro supletorio, folio 381, inscripción 543 .

Por ello, a pesar de tratarse de una copia posterior al documento inicial y ante la imposibilidad de aclarar esta cuestión con familiares directos del pintor, citaremos su segundo apellido en los términos de la mencionada partida y mantendremos los textos originales según la redacción de los distintos autores.

12 Garcia Maroto, G. El año artístico... Op. Cit. Pág. 42 y ss. La misma fuente de inspiración en la obra de Dante será señalada años más tarde por José Francés.

13 «El color de los dulces sueños» que inspirase a Rubén Darío y símbolo colorista del arte mallarmiano.
} 


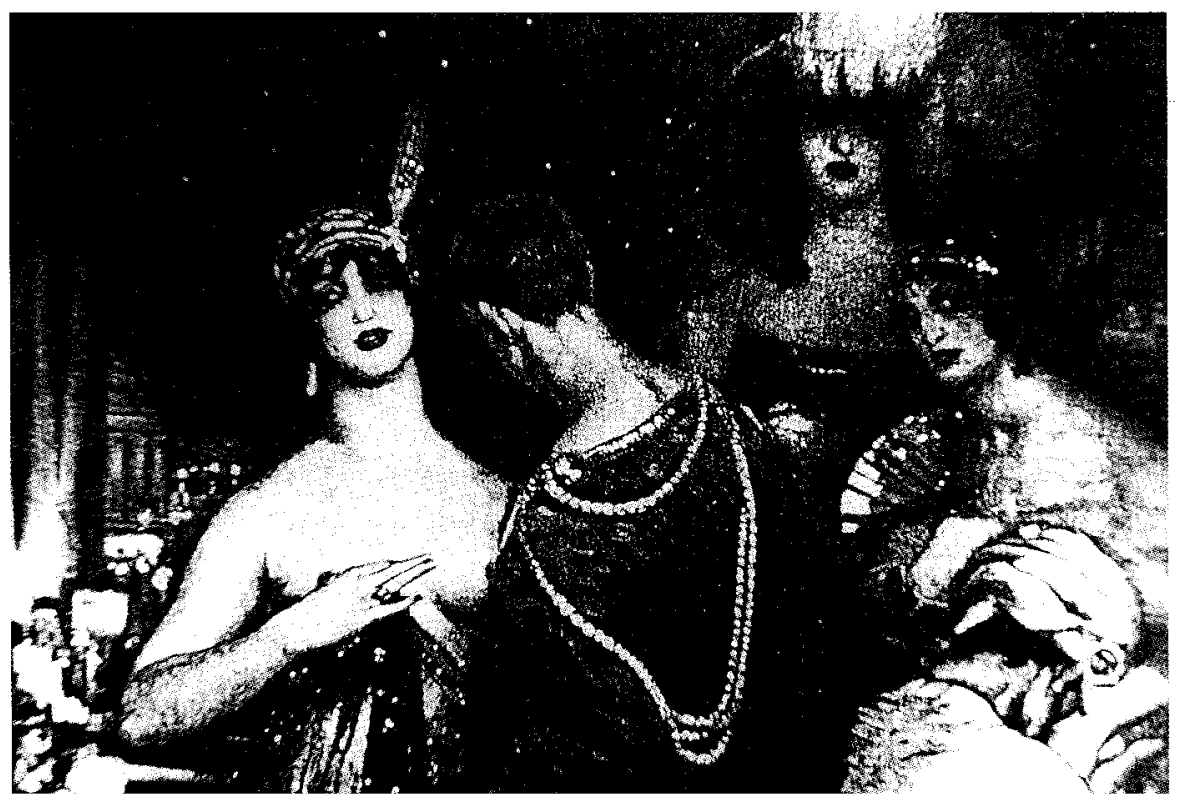

Fig. 1. Noche galante. 1914. Adquirido por S.M. Alfonso XIII.

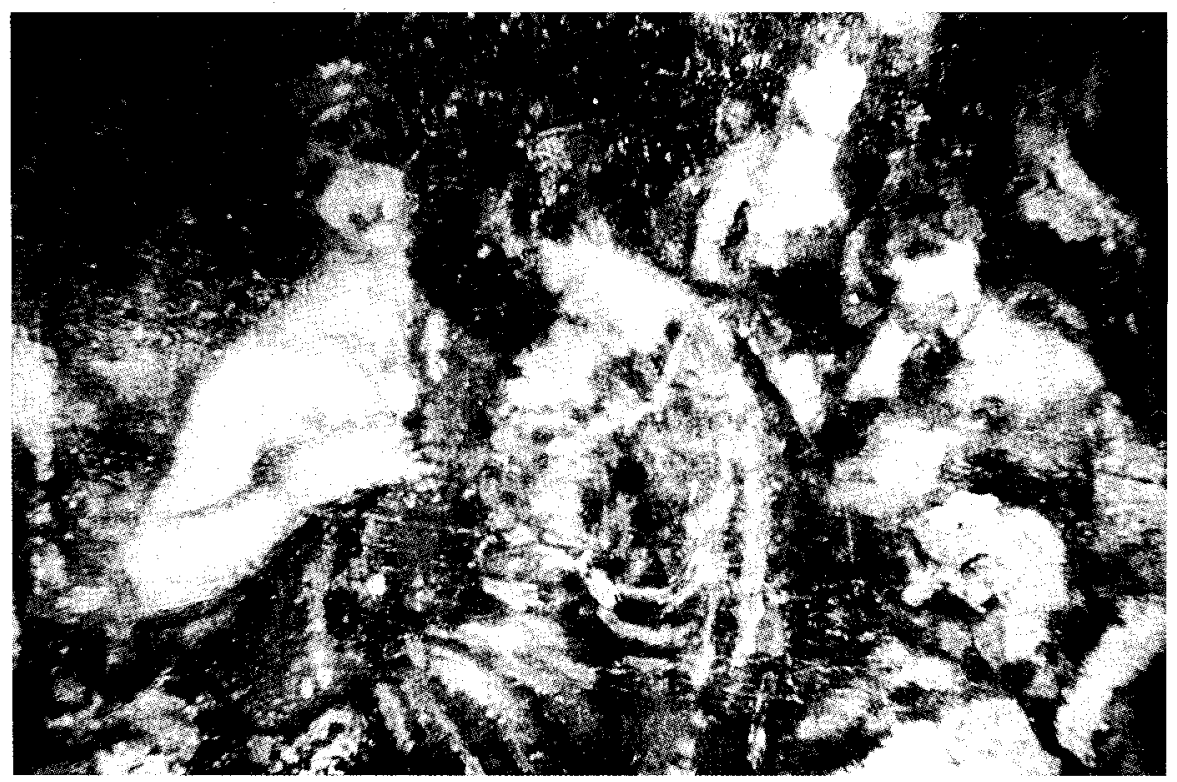

Fig. 2. Noche galante (boceto). 1914. Casa de Alba. Dedicado y fechado en 1920. 
Rachilde («con la noche hizo el día», dirá después Ventura García Calderón a propósito de ellos).

Desde su estudio de Travesera de Dalt, alejado del oficialismo madrileño y del simbolismo castizo del Nuevo Levante pero también del nou centisme mediterráneo, recreaba en estas obras su propio universo cotidiano, personajes salidos de la literatura oriental, la Biblia precristiana y la mitología griega; jardines simbolistas de Klingsor o Armida; y animales propios del atrezzo hindú: «Podrá decirse que su alma encontró un espejo exacto, como el espejo a que se miran los pavos reales en (...) las umbrosas y perfumadas avenidas del señorial parque de los Beltrán» ${ }^{14}$.

Su relación con José Francés, crítico de La Esfera bajo la firma de Silvio Lago, le convirtió en el pintor de los literatos galantes con los que mantuvo una productiva amistad. El propio Francés le proporcionó sus traducciones de Poe o Pierre Louys, y le inspiró su afición por la Thais de Anatole France. Fruto de esta relación es la aparición de temas abiertamente eróticos, reflejo del simbolismo más explícito y de un esteticismo premeditado que no fueron entendidos por el público ${ }^{15}$. Nace ahora una de sus obras más emblemáticas: Canción de Bilitis (fig. 3), exaltación del desnudo y la sensualidad femeninas a través de los versos de la poetisa griega imaginada por Louys y trasunto de las femme fatales finseculares, cuyas actitudes insinuantes y voluptuosas evocan a Fernand Khnopff o von Stuck. Es el tipo de mujer que Bornay define como «bailarina de belleza turbia y perversa, lujuriosa y felina» 16; la que Pater viese en el rostro de Gioconda: "Una belleza elaborada desde el interior de la carne (...) el animalismo de Grecia, la lascivia romana, el misticismo de la Edad Media, el retorno al mundo pagano y los pecados de los Borgia» ${ }^{17}$; la que Moreau - Beardsley pintasen en Salomé; pero, sobre todo, la Damayanti que un año antes describiese Francés en su novela La Danza del Corazón: «El furor demoníaco encendía sus carnes, nublaba sus ojos y vibraba en sus nervios. Era una faunesa, una bacante enloquecida por las canciones fálicas y órficas; era la impúdica sacerdotisa de las bransomias... ". El tema estaba basado en uno de los ideales de belleza característicos del simbolismo: el

14 Lago, S. «El arte catalán contemporáneo». Rev. La Esfera, n. ${ }^{\circ}$ 91. Madrid. 1915.

15 Debido al tradicionalismo del carácter español, según José Francés. En Francés, J. Federico Beltrán Masses. Madrid. Biblioteca Estrella. S/a. Pág. 7. La base fundamental de este estudio había sido publicada en la revista Museum en 1917, apareciendo ligeras modificaciones en la edición reseñada, a partir de un artículo suyo publicado en La Esfera en 1918 donde se recogían sus últimas obras parisinas, en ningún caso más tarde de 1920 (fecha proporcionada por John O'Neill, curator, manuscripts \& rare books de la Hispanic Society of America de Nueva York).

16 Bornay, E. Las hijas de Lilith. Madrid. Cátedra. 1995. Págs. 113-117.

17 Pater, W. El Renacimiento. Barcelona. Icaria. 1982. Págs. 101-102. 
Pintor de almas en la moderna Babilonia. Tardosimbolismo y déco en la pintura...

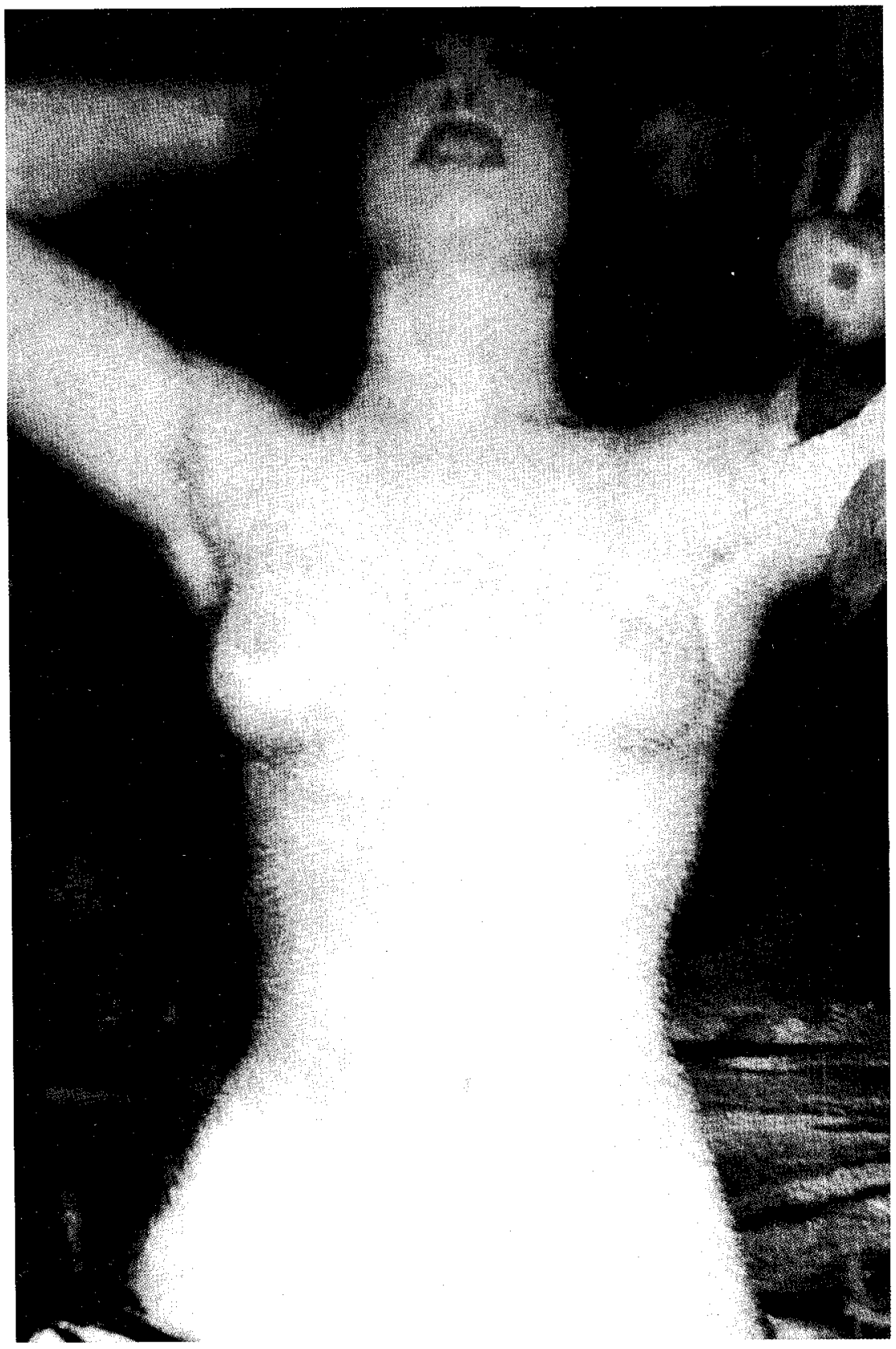

Fig. 3. Canción de Bilitis. 1914. Colección particular. 
desnudo femenino en su versión más pecaminosa, tratado con «una voluptuosidad ofrecida para el deleite de la mirada y el intelecto ${ }^{18}$ que cultivará hasta los años veinte.

Noche Azul y Canción de Bilitis junto a otras sesenta y una obras fueron presentadas ese año en la sala Parés de Barcelona. La exposición suscitó opiniones controvertidas entre la crítica de la época, pero en general bastante favorables, aunque no siempre por una misma razón. Folch - crítico del Diario de Barcelona - felicitaba al autor y sus lienzos desde su academicismo ${ }^{19}$, sin embargo Francés lo alababa por unas soluciones contrarias, en las cuales él mismo tenía mucho que ver: «El misterio de los cielos nocturnos», «los jardines perfumados de amor» $y$ «las mujeres desnudas en toda la limpia y serena euritmia» ${ }^{20}$. Con grandes dosis de entusiasmo, para el escritor representaba la exposición que consagraba a Federico Beltrán entre la vanguardia artística española, pero sí es seguro que con la presencia de cuartetos de cuerda y otros espectáculos para atraer al público a su estudio inauguraba una faceta de pintor mercantilista que le acompañaría a lo largo de su vida.

A esta misma exposición había presentado lienzos como El primogénito o Mely y Xuty que ampliaban su fértil iconografía tardosimbólica. El primero estaba inspirado por un tema tan en boga como la Comedia del Arte. La joven y frívola Colombina se exhibía desnuda ante un Pierrot de apariencia narcotizada en un contraste efectista, síntesis de morbidez y elegancia prerrafaelita. Mely y Xuty (fig. 4), retratos de la familia Narezo ${ }^{21}$, se conciben como estereotipos de la belleza femenina de Beltrán, evocadora de Leonardo e inspirada por la dualidad del D'Annunzio de El Placer y la modernidad de la Eva Futura de Villiers. Algo andróginas, mezcla de una ingenuidad y perversión reflejadas por rostros extremadamente pálidos, seriados e indefinibles; como siempre, sobre fondos coloristas de pincelada suelta, con escenas en segundo plano y temática recurrente: personajes orientales, grandes carruajes, toreros y majas..., símbolos atávicos de una sociedad decadentista que responde al progreso con la búsqueda de un primitivismo vernáculo.

El año 1915 resultará clave en la trayectoria futura, personal y artística, de Federico Beltrán. En la línea de los cuadros de temática erótica que había expuesto meses antes en Barcelona, realiza La Maja Marquesa (fig. 5) y el Desnudo de Mirabella con el propósito de presentarlos a la

\footnotetext{
Francés, J. Federico... Op. Cit. Pág. 8.

Datos obtenidos del archivo de la sala Parés (Barcelona). Carpeta: Beltrán Massés.

Francés, J. Federico... Op. Cit. Pág. 16.

Irene Narezo Dragone, también pintora, contrajo matrimonio con Beltrán el 27 de septiem-
} bre de 1911. 
Pintor de almas en la moderna Babilonia. Tardosimbolismo y déco en la pintura...

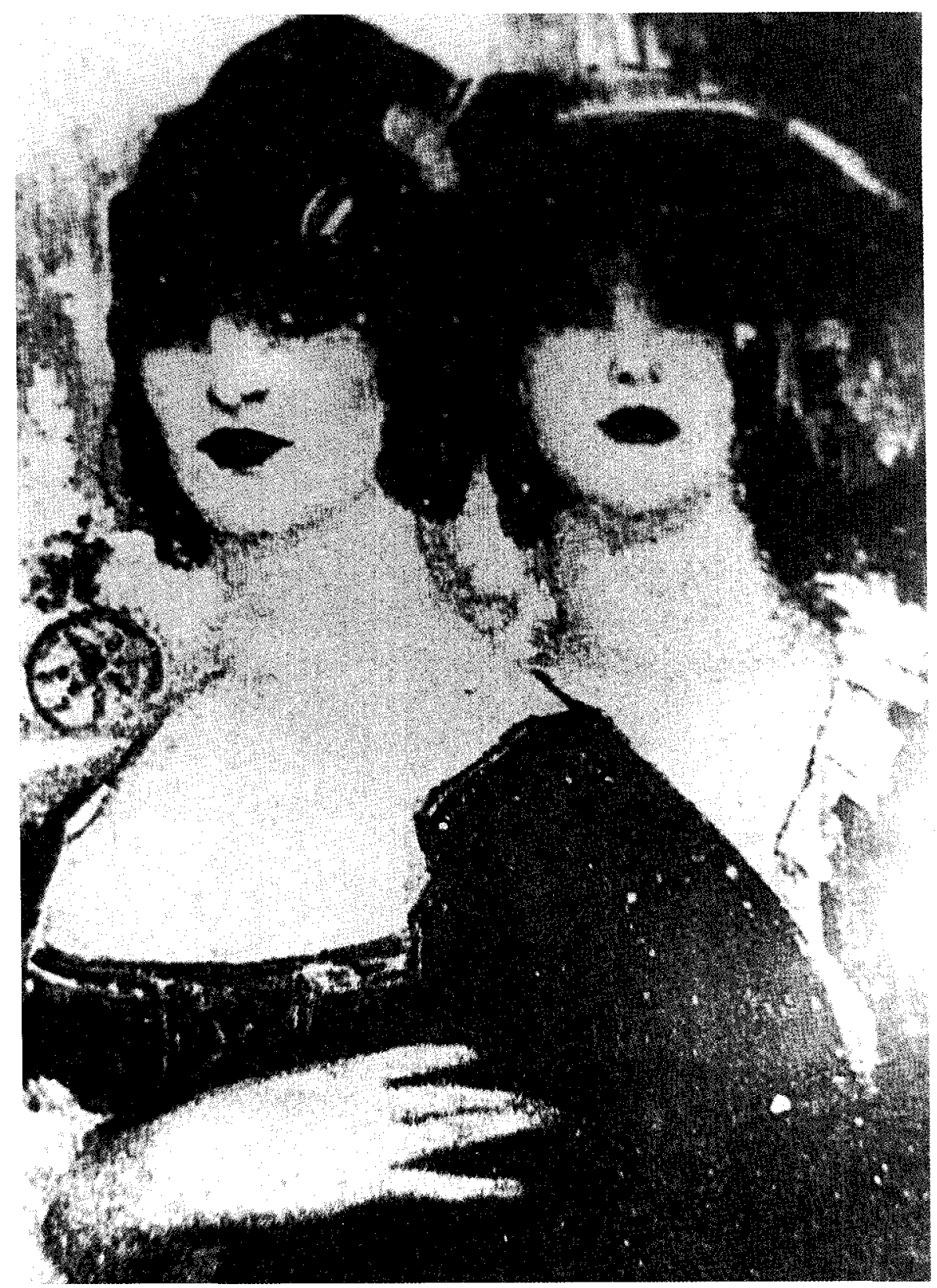

Fig. 4. Mely y Xuty. 1914. Reproducido en la portada de La Esfera $n .^{\circ} 92$. 


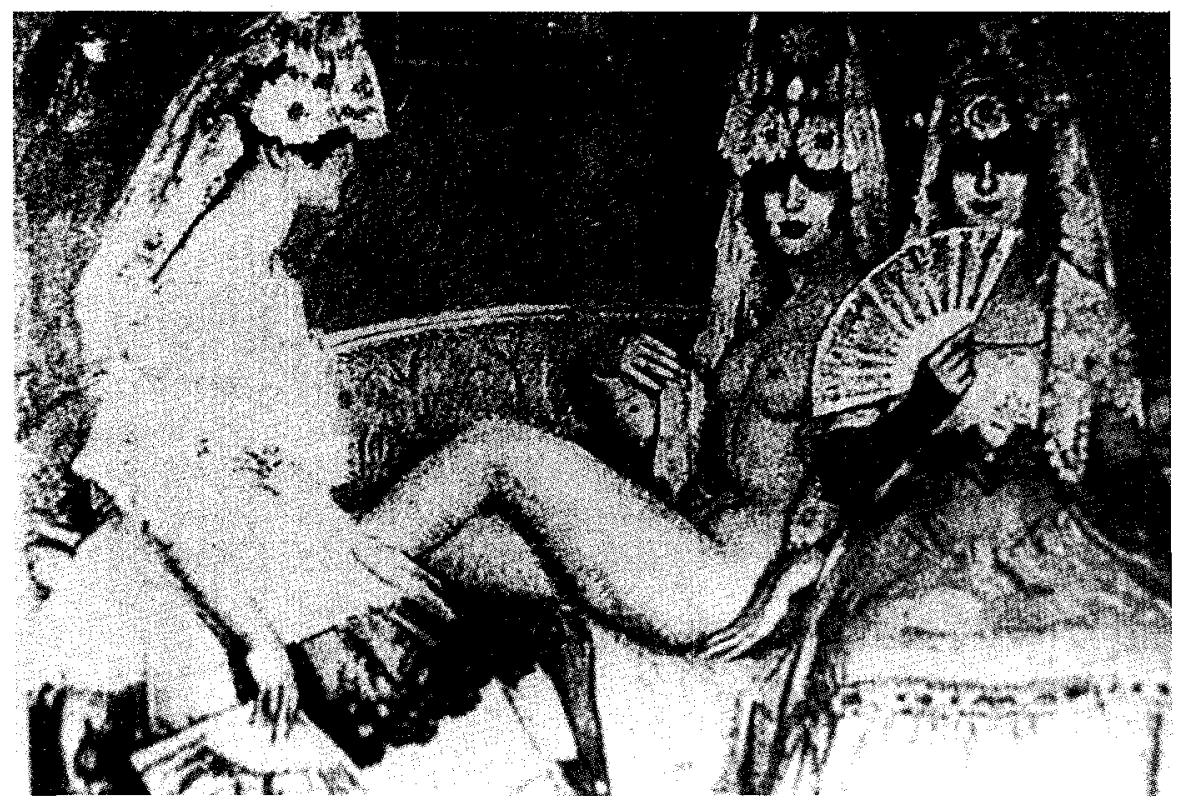

Fig. 5. La Maja Marquesa. 1915. En paradero desconocido.

Exposición Nacional de ese año. El jurado madrileño, dando muestras de gran mojigatería, no podía tolerar entre la colección un cuadro en el que parecía retratarse «a cierta individua, marquesa y lesbiana, que lleva una vida de escándalo» ${ }^{22}$. La obra era ciertamente atrevida para la ocasión, sendas majas rodeaban a otra tercera - la marquesa - recostada sobre un diván de época y tocada sólo con una mantilla blanca y un pequeño pañuelo en su mano. El problema, sin embargo, no parecía estar en el tema sino en el título, que debió entenderse como una crítica más o menos velada hacia una parte de la alta sociedad, casquivana y salaz. La anécdota, en cualquier caso, refleja las mismas trabas que tuviese Romero de Torres en las Nacionales cuando el tema del desnudo femenino iba más allá de lo mitológico y evidencia el atraso del mundo pictórico oficial. Beltrán rechazó sustituir el título por el de «Las Majas», tal y como le había propuesto el jurado para su admisión, y expuso la obra en el Salón del Arte Moderno. El consiguiente escándalo le proporcionó la popularidad que hasta entonces no había tenido en Madrid, así como el reconocimiento definitivo de un sector de la crítica y de sus propios compañeros.

22 Palabras textuales del jurado según Francés. En Francés, J. Federico... Op. Cit. Pág. 12. 
La polémica apareció ampliamente reflejada en prensa: Nuevo Mundo, El Año Artístico, El Indiscreto, Día Gráfico, Heraldo de Madrid o La Patria se hicieron eco del caso. Desde las páginas de La Tribuna, Rafael Cansinos Assens contraponía La Maja Marquesa a la mediocridad general de la muestra y del propio jurado ${ }^{23}$, y García Maroto publicaba poco después su libro de desagravio Federico Beltrán y la Exposición Nacional de Bellas Artes de MCMXV, en el cual defendía la renovación plástica de la obra de Beltrán a través de la imagen del desnudo: «No son Federico Beltrán y La Maja Marquesa sino puntos de apoyo para el hermoso movimiento de traslación que deseamos imprimir al mundo artístico español. No veáis un fin en el comentario del admirable artista (...); ved sólo un medio de que nos valemos para purificar el ambiente, enrarecido por la envidia, y limitado por la mediocridad» 24 . Otros pintores también tomarán partido en la controversia, Marceliano de Santamaría, por ejemplo, escribirá a propósito del lienzo: «Me atraen irresistiblemente los cuadros entonados; si además son armoniosos se eleva para mí el mérito de la obra; y si a estas cualidades se suma la dulce coloración, entonces la atracción se torna en respetuoso acatamiento del mérito. Así veo yo el cuadro de Beltrán, no hallo otras cosas en La Maja Marquesa» ${ }^{25}$. Estas palabras de Santamaría resultan elocuentes para entender la profunda separación que, mediados los años diez, existía entre el arte más académico y ese otro que por entonces se entendía como el arte de vanguardia en España y que, aunque alejado de las experiencias cubistas y futuristas europeas, lo estaba también del oficialismo más convencional para el que constituía una amenaza.

El escándalo que siguió a la presentación en sociedad de La Maja Marquesa le abrió definitivamente las puertas de la capital, compartiendo esporádicamente la tertulia de Antonio de Hoyos y Vinent - a quien retrató en varias ocasiones - con personajes de la nueva sociedad como la bailarina Tórtola Valencia, el dibujante úosé Zamora o el escultor Julio Antonio. Junto a Zuloaga, Romero de Torres y Bartolozzi realiza ahora una serie de ilustraciones para Mientras en Europa mueren..., una novela corta publicada por el marqués de Hoyos en la colección Los Contemporáneos.

\footnotetext{
23 Cansinos Assens, R. «El reinado de la mediocridad. La Maja Marquesa, de Beltrán». La Tribuna, de 4 de mayo de 1915. Págs. 67-70.

${ }_{24}$ García MAROTO, G. Federico Beltrán y la Exposición Nacional de MCMXV. Madrid. Imprenta española. 1915. Pág. 8. Cfr. Serrano de LA Cruz Peinado, A. Las artes plásticas en Castilla-La Mancha. De la restauración a la /l República (1875-1936). Toledo. Junta de Comunidades de CLM. 1999. Pág. 243.

25 Santamaría, M. "Cuadro de Federico Beltrán titulado Noche Azul». Boletín de la Academia de San Fernando. Madrid. 1916.
} 
La influencia de éste se acentúa a partir de esos momentos en la pintura de Massés, cuyo simbolismo se hace más crepuscular con temas de un erotismo pasional, lascivo y fetichista, teñido en ocasiones de la mitología opulenta de Dionisios y Demeter o la religiosidad morbosa de Susanna (fig. 6), quizá inspirada en la novela de aquel El Monstruo, publicada en 1915 y arquetipo de las relaciones pecaminosas entre púberes y adultos, rasgo común en las novelas decadentes desde Mirabeau o la Claudine de Colette. La estética del escritor está presente, sobre todo, en la anticipación de cualidades características del primer déco, mujeres ambiguas y una sociedad en la que se aúnan decadencia y modernidad bajo una estética de lo más kitsch: «Nubes de gasas, tules y encajes moldeando cuerpos de formas inverosímiles - demacrados como figuras bizantinas...-, guirnaldas de rosas, de lirios y de orquídeas; enormes pamelas empenachadas de nervadas plumas que caían Iloronas sobre cabelleras teñidas de matices inquietantes, irisadas de rojas llamaradas, de pálidos reflejos de oro, de azuladas negruras de noche (...) formaban, envueltos en un aura de violentísimos perfumes, un conjunto abigarrado de elegancia insólita un tanto estrepitosa» ${ }^{26}$.

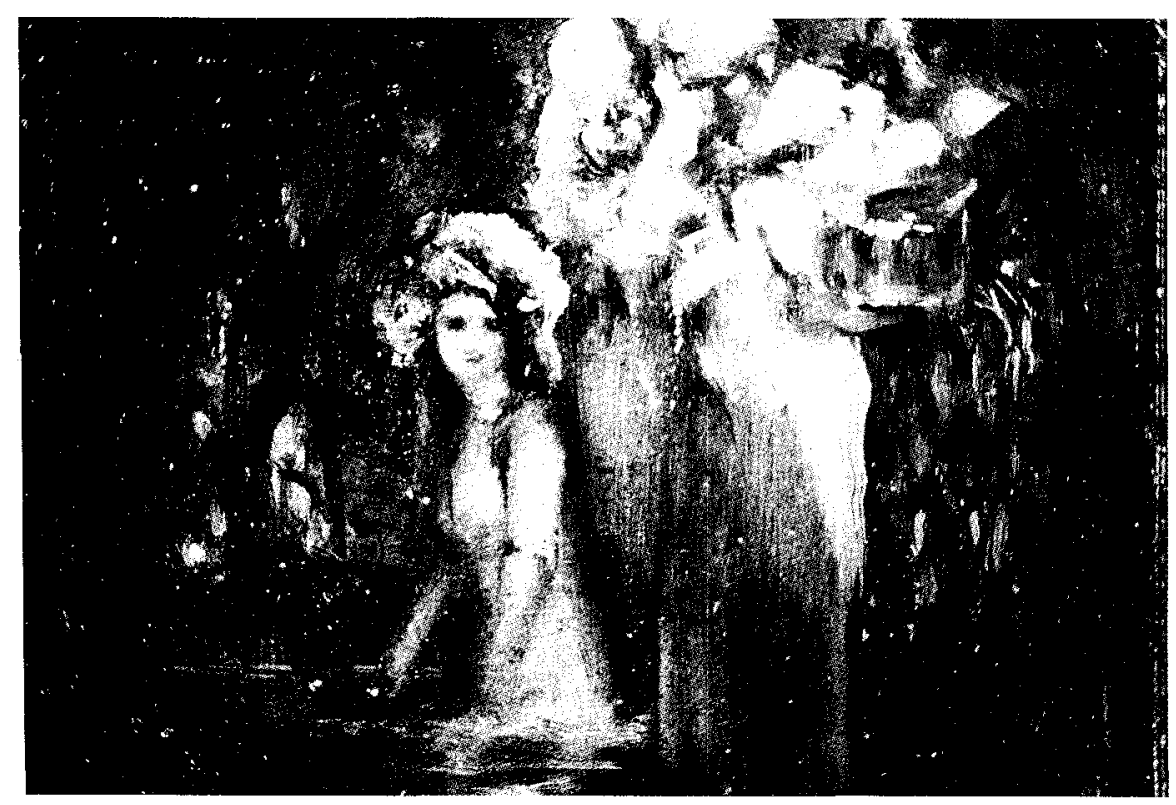

Fig. 6. Susanna. 1916. Museo de Arte Moderno. Barcelona.

26 Hoyos y VInent, A. La vejez de Heliogábalo. Madrid. Renacimiento. 1912. Págs. 29-30. 
De este periodo, y en relación con obras de temática similar en Romero de Torres, Zuloaga o Maeztu, es su serie de cuadros de «majas púdicas», una concesión al maniqueísmo más conservador frente a La Maja Marquesa. Las voluptuosas anatomías femeninas desnudas dejan paso a una exaltación de colores en sus indumentarias, como en la Maja con mantilla y abanico (fig. 7), cuadro que estuvo entre los preferidos de Ismael Smith. No hay concesiones a la modestia, por el contrario todo está concebido con un barroquismo ornamental exagerado: "Una exaltación divinizadora del color y de la idea (...) para el deleite de la mirada", explica Silvio Lago ${ }^{27}$. Es la aportación de Federico Beltrán al modismo goyesco que triunfa en España y en el mundo gracias a la música de Granados y Periquet, al ballet de María Kousnezoff, a los figurines de Néstor o a la nueva imaginería picassiana. «En Nueva York se vieron peinetas por todas partes» publica La Esfera en un número de la época ${ }^{28}$, aludiendo a la españolización cultural que se estaba produciendo de un tiempo a esta parte en las sociedades más desarrolladas, y Beltrán parece querer aprovechar la coyuntura para dar el salto a la capital artística por excelencia: París.

Antes celebrará una última exposición en el hotel Palace de Madrid, en marzo de 1916. La muestra, a pesar de su coincidencia con otras de Zuloaga, Cabanas, Oteiza y Rusiñol, resultó la más exitosa del pintor en nuestro país. En este sentido, Hoyos y Vinent recuerda en textos posteriores la calurosa acogida del público y la algo más fría de sus compañeros, y como se vendieron gran número de obras entre aristócratas, millonarios y «hasta el mismo rey Alfonso XIII dio el ejemplo" ${ }^{29}$. Se recogían setenta y ocho cuadros que compendiaban el tardosimbolismo de su última producción. Era en esencia una muestra de despedida, previa a su inmediata partida hacia Francia, y la crítica artística quiso hacer balance de su obra. En su crónica de la exposición, Silvio Lago habla de «una exaltación optimista del espíritu" y alude a la variabilidad de sus telas que «desde las notas frías, finas, envueltas en una serenidad de composición y de colorido, llega a otras cálidas, enérgicas, vibrantes, cargadas de luz y fuerza", asociando las primeras a los cuadros de gran formato y las segundas a los abundantes bocetos preparatorios, que muchos comparaban con el neoimpresionismo de Monticelli, según un procedimiento pictórico muy habitual en la producción de Beltrán (ver figs. 1 y 2). Al mismo tiempo,

\footnotetext{
27 LAGo, S. «Federico Beltrán Masses». Rev. La Esfera n. ${ }^{\circ} 92$. Madrid 2 de octubre de 1915. $28 \quad 22$ de abril de 1916.

29 Hoyos y VINENT, A. «Una impresión de visita al estudio de Federico Beltrán». En Francés, J. Federico... Op. Cit. Págs. 33-37.
} 


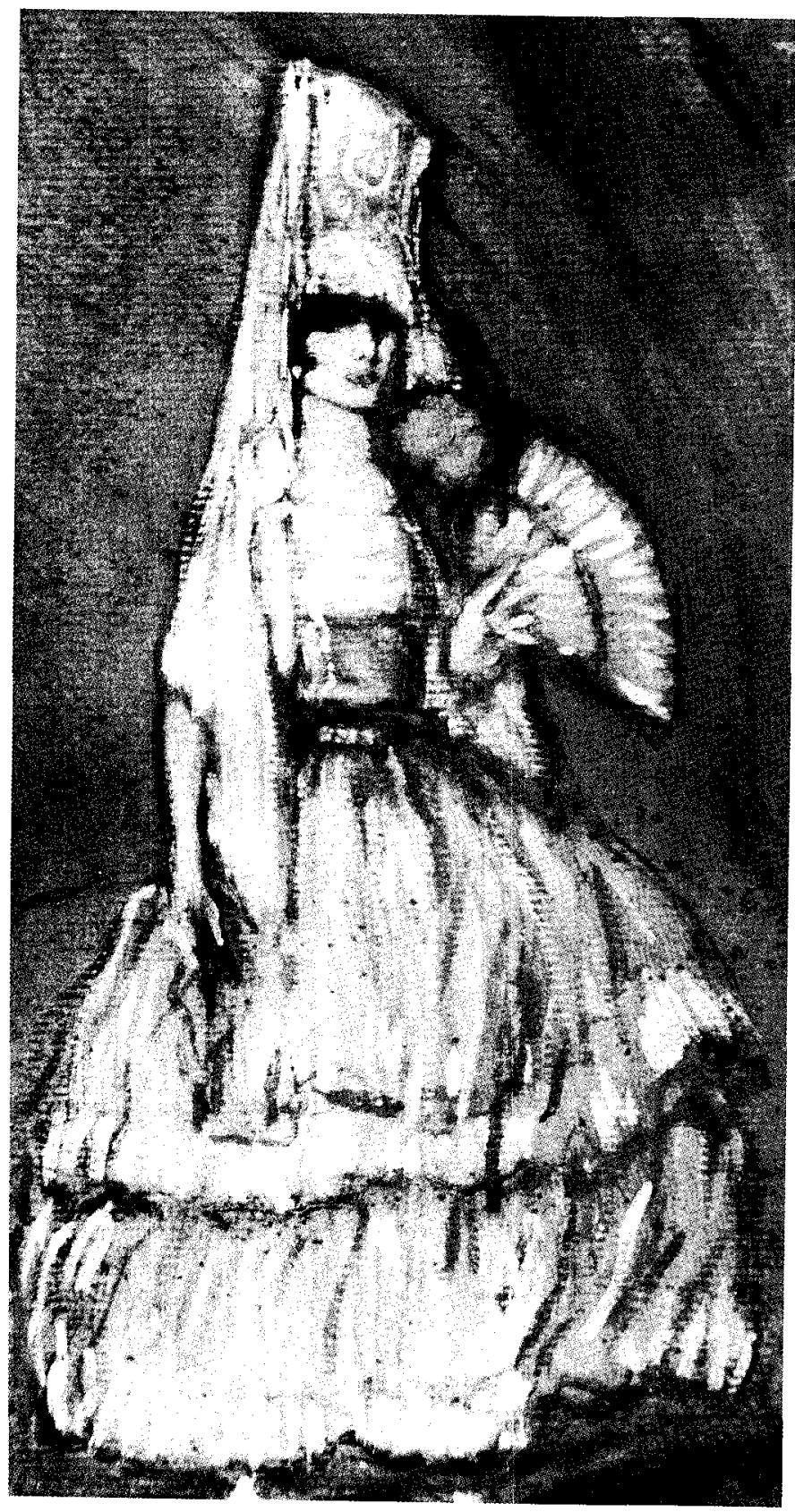

Fig. 7. Maja con mantilla y abanico. h. 1916. Museo de Arte Moderno. Barcelona. 
Lago significaba la individualidad de su pintura y expresaba sus propios gustos estéticos: "No parece un pintor español, pues no hallamos en él la tradición pesimista, seca y austera (...) que nos legaron nuestros pintores del XVII y que siguen considerando como única forma de belleza algunos pintores contemporáneos», por el contrario «su obra es música del alma y caricia de los sentidos» ${ }^{30}$. Silvio Lago y el crítico de Blanco y Negro convenían en destacar el éxito del lienzo Hacia las Estrellas ${ }^{31}$, donde volvía a retomar el casticismo de los temas a través de un grupo de gitanos tratados aquí bajo la perspectiva bucólica e idealizada de la vida itinerante. Tenía esta obra todas las características para gustar al gran público: el tema era de un simbolismo un tanto ramplón pero comprensible, las figuras iban decorosamente vestidas y el marco, lleno de guitarras y caballos -imágenes de una modernidad muy aprehendida-, era de lo más efectista.

Sin embargo, otras telas reflejaban mejor su evolución pictórica. Por ejemplo, Intimidad o La Iniciada, que ejemplificaban un gusto por la transgresión y el malditismo adquirido del díscolo marqués, «un muchacho de talento, acometido de loco prurito de llamar la atención, al que todo lo sacrificaba con sus toilettes de poeta romántico y sus exageraciones que le habían dado fama de extravagante» ${ }^{32}$. El primero de los dos lienzos reunía a dos figuras femeninas (una vestida y otra desnuda) abrazadas, evocadoras de Tiziano y el más próximo Romero de Torres, en alusión a la homosexualidad femenina inspirada por la mixtificación literaria de Bilitis. El lesbianismo se entendía desde el lado contradictorio y perverso del fin de siglo, y Beltrán se convertía con esta obra en heredero de los pintores simbolistas que transcribieron con sus pinceles los versos de Swinburne o Verlaine dedicados a Safo. En 1916 preludiaba también la recuperación del papel social de lo femenino desde la reivindicación de su propio sexo, como defenderá más tarde el déco de las ilustraciones frívolas de Barbier, Penagos o Ribas Montenegro. La Iniciada explicitaba el tema de la prostitución en una obra de enorme erotismo donde la retratada insinuaba uno de sus pechos tras unas gasas transparentes, expresión del placer delicado y turbio del simbolismo más oculto. En Invocación a Laksmy, por su parte, el amor se observaba desde el lado amable del pintor hispano-cubano, fascinado aquí por un orientalismo muy de moda en nuestro país

30 Lago, S. «La exposición de Beltrán en Madrid». Rev. La Esfera n. ${ }^{\circ} 117.25$ de marzo de 1916.

31 «La semana gráfica de todas partes: exposición de obras del pintor Federico Beltrán en el Palace-Hotel (Madrid) ». En Blanco y Negro n. ${ }^{\circ} 1.297$. Madrid, 26 de marzo de 1916.

32. Según retrato de su alter ego literario Julito Calabrés en su novela Frivolidad de 1905. Cfr. Gálvez YAGüe, J. "Vida y obra de Antonio de Hoyos y Vinent». En Hoyos, A. Sangre sobre el barro. Madrid. Cairel. 1993. Págs. 303-304. 
desde principios del siglo $x x$ y que los escritores galantes contribuyeron a revitalizar. En sus manos, ese interés por culturas distantes adquiere un carácter decadente y de curiosa hispanidad, mezcla del esteticismo de las blondas, los jardines y los pavos reales con alusiones cultas a la diosa hindú del amor y jóvenes con turbante tocando la guitarra española.

Por último, abundaban en la exposición los cuadros de "genero tópico», algunos teñidos del misterio de unos espacios claustrofóbicos como La Súplica y otros, como Primavera, en los que el subyugador paisaje suplanta al tema principal. Asimismo, eran numerosos los retratos, entre los que destacaba el de Amparo de Córdoba quien, vestida de torero y peineta, desafiaba al espectador español con su mirada arrogante y unos signos familiares al servicio de la infracción... Este cuadro resume el presente y el futuro de la obra de Beltrán. El espíritu tardosimbolista del pintor insistía en el tema de la androginia femenina mediante el travestismo del personaje y en el interés por lo remoto expresado a través del ánfora de apariencia arqueológica que complementa la obra; el futuro, a veces condicionado por lo económico, pasaba evidentemente por el cultivo del retrato de los grandes personajes de la sociedad déco.

Poco después de la exposición del Palace Federico Beltrán se instala en París, estableciendo su estudio en el número doce de la Ville Guibert en rue La Tour. Como corresponde a la personalidad del pintor y a su particular visión mercantilista del arte — «sabía diplomacia lo que contribuyó, aparte del valor de su obra, a la difusión de sus éxitos por el mundo", escribía Francisco Serra ${ }^{33}$ - su estudio no podía ser nada convencional: «El ambiente era un tanto teatral y decadente, perfumado con sándalo y envuelto en una suave penumbra. El gran salón, donde se sentaban los amigos en enormes y acogedores divanes, tenía al frente una puerta que comunicaba con otro más pequeño, que era en realidad el verdadero estudio. En éste sólo había una tarima llena de cojines, sobre la que posaban los modelos y, en el centro, de cara a la puerta, un gran caballete donde necesariamente se colocaban los cuadros para ser admirados. Un criado negro, uniformado elegantemente, exhibía los lienzos..." ${ }^{34}$.

Su primer contacto con el mundo parisino lo realiza a través del consulado de España donde, casi recién llegado, expone La Maja Maldita (fig. 8), una nueva y peculiar versión de la mujer goyesca, «muy vamp, perversa y

\footnotetext{
33 Serra, F. Nuestros artistas. Reportaje gráfico, documental y anecdótico. Barcelona. Edimar. 1954. S/p.

34 Ontañón, S. y Moreiro, J.M. Unos pocos amigos verdaderos. Madrid. Fundación BEX. 1988. Pág. 24.
} 


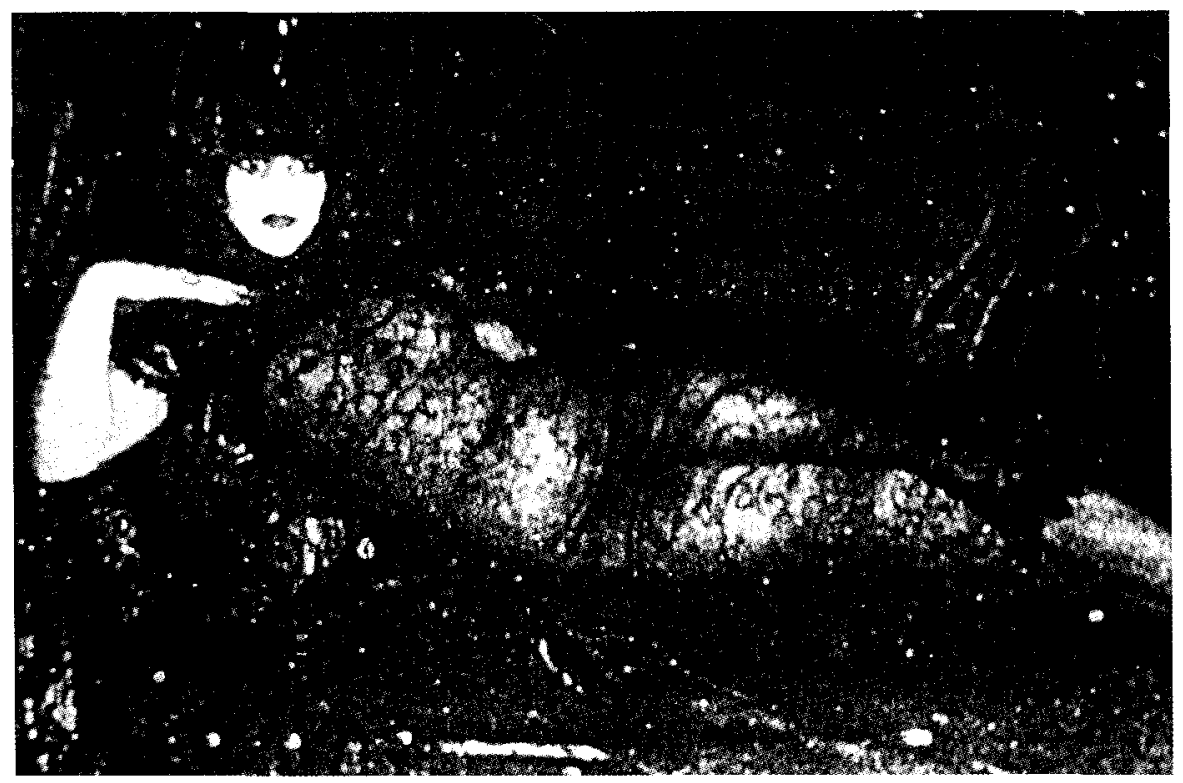

Fig. 8. La Maja Maldita. h. 1917. Paradero desconocido.

hasta algo tigresa, tocada con una peineta cuya amplia y fina mantilla cubre su cuerpo desnudo que se transparenta bajo el fino encaje», según la describe Pérez Rojas ${ }^{35}$. La nueva maja estaba en la tradición de una tema muy popular desde la España romántica, del cual Beltrán había sido uno de sus máximos cultivadores. Sin embargo, inauguraba además un tratamiento nuevo del mismo; pasada por el cedazo parisino, la maja había perdido la «ingenuidad» de sus características peinetas blancas y vestía ahora de un luto riguroso. Pero por encima de este hecho, que se acentúa definitivamente con La Maja de Luto, lo que se adivina en ellas es una mayor internacionalización. La españolidad, que había sido su símbolo distintivo, pasa a un segundo plano, mientras la maja se acerca cada vez más a las modelos de la aristocracia. En 1918 el Retrato de Mlle. de Bastat culmina este proceso. La figura de la dama francesa es estilizada, elegante y muy sofisticada, como la nueva sociedad, vestida por Paul Poiret, Jan Patou o Nina Ricci. Su estilo es limpio y depurado, muy déco, contrastando con las imágenes subconscientes del fondo del lienzo: toreros, gitanos y una maja enlutada en la sombra: "Simbólicamente, esta figura de mujer dolorida y

35 Pérez Rojas, J. Art Déco en España. Madrid. Cátedra. 1990. Págs. 255-257. 
morena rinde tributo a la serena y rubia, eje luminoso del cuadro, es un homenaje estético» ${ }^{36}$. Es el paso definitivo desde el simbolismo tardío de raíz hispánica hasta el cosmopolitismo de la sociedad parisina, desde el casticismo temático finisecular hasta el retrato aristocrático de entreguerras.

Obras como Adzhara en la danza de la abeja son también plenamente déco. Una bailarina de rasgos andróginos es representada de perfil egipcíaco mientras mueve pies y manos, cubriendo con sus ropas transparentes un fondo de exuberancia decorativa y floral. Todavía se advierte una cierta inspiración nouveau en la sinuosidad de las líneas, pero esencialmente destaca por su primitivismo, por un movimiento inspirado en Nijinski - la Duncan y «por la serie de modernas y ultracivilizadas paganías» ${ }^{37}$ que preludian los alegres veinte. Sin embargo, no olvidará Beltrán durante los primeros años de estancia en París sus cuadros de siempre. Los de

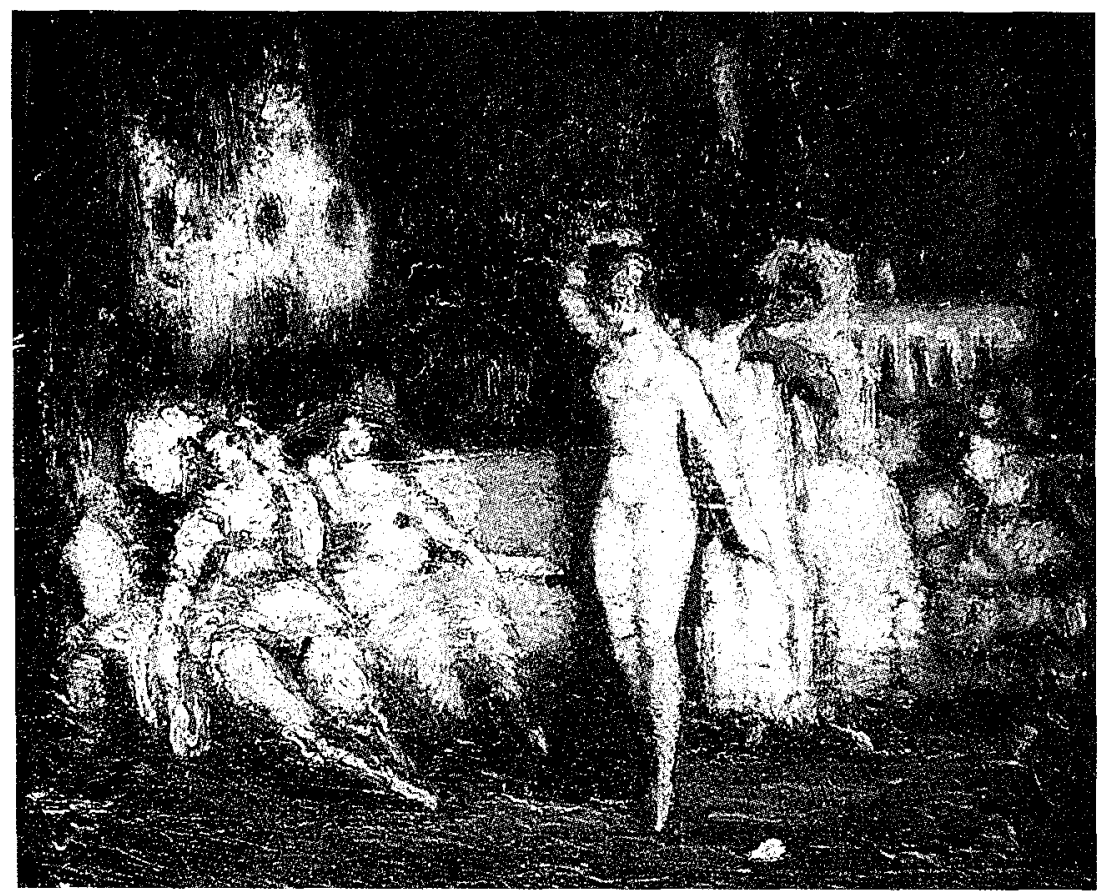

Fig. 9. Salón (las horas españolas). Colección particular.

36 LaGo, S. «Las últimas obras de Beltrán». Rev. La Esfera n. ${ }^{\circ}$ 218. Madrid. 1918.

37 Comentario textual de Francés a propósito de la mencionada obra. En Francés, J. Federico... Op. Cit. Pág. 30. 
nocturnos galantes, con fuerte contenido erótico y evocadores de jardines misteriosos imaginados por Amado Nervo o Julián del Casal, como en Salón (fig. 9). Tampoco los del españolismo más castizo, de abanicos, guitarras, peinetas, toreros y tonadilleras, sin renunciar a una cierta sensualidad sugerente y a la técnica impresionista (Boceto, fig. 10). Ni siquiera los de temática alegórica, que se centran en las representaciones del heroico Paris, las bíblicas Berenice y Salomé, la frutal Pomona o el bestialismo de Leda (Leda, La hija de Leda, Leda Azul...), símbolo del decadentismo final representado por el célebre poema de Yeats (Leda \& the Swan, 1923) a través del cisne, imagen de una belleza condenada por la civilización del progreso. Salomé (fig. 11) será considerada por Hoyos como su obra maestra, «la que suspende de pasmo y cautiva en su inquietud muy antigua y por lo mismo ultramoderna (...) Hay en ella una sensualidad tan densa, tan atormentada, tan violenta, que la figura de la hija de Herodías deja de ser una mujer y conviértese en un símbolo de cosas eternas, horrendas y escalofriantes" ${ }^{38}$. La personificación de la sicalipsis femenina del fin de siglo es curiosamente el epílogo del simbolismo de Beltrán. Despúes pintará alegorías del carnaval y no olvidará su

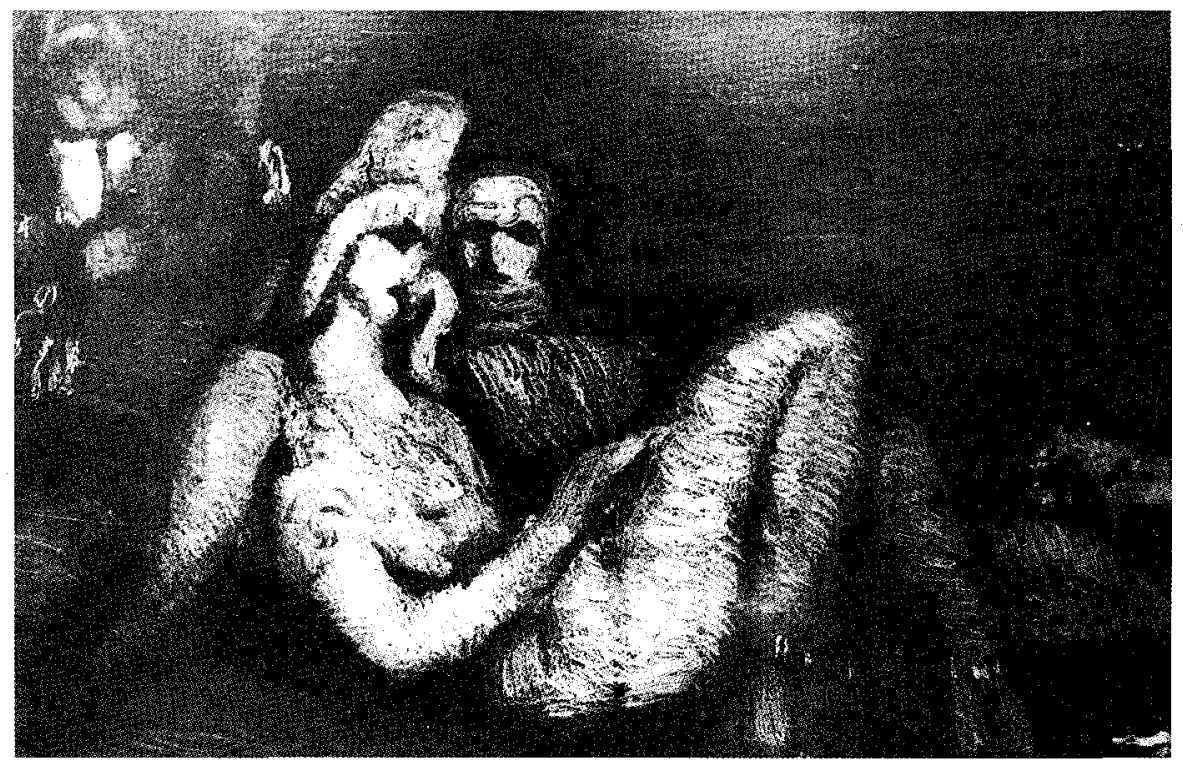

Fig. 10. Boceto. h. 1918. Museo de Bellas Artes de Asturias. Oviedo.

38 Hoyos y Vinent, A. Una impresión... Op. Cit. Pág. 37. 
pasión por Oriente, pero sus referentes no serán ya los de una literatura decadente y compleja, sino los de la linealidad simplista y el maquinismo artístico déco: «síntesis de Sherezade, el recién descubierto folklore de Europa Oriental, la estilización de algunos motivos Art Nouveau y formas clásicas de corte geométrico... ${ }^{39}$.

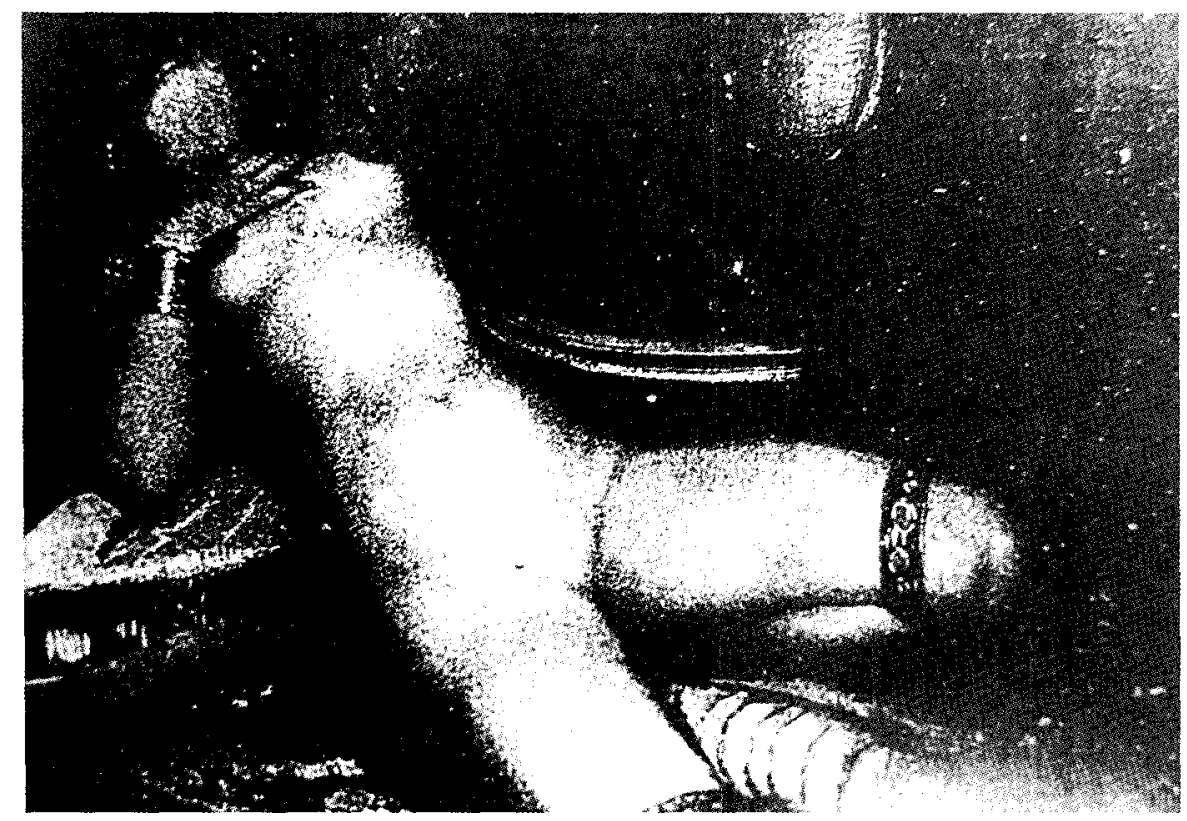

Fig. 11. Salomé. h. 1918. Paradero desconocido.

El éxito de la pintura de Massés fue casi inmediato entre la alta sociedad francesa. En 1919 participaba en la exposición de arte español del Petit Palais y muchos pensaron en él como un nuevo Goya o Zuloaga. Su Maja Maldita despertaba el interés de un público que se veía retratado en óleos de enorme elegancia, técnicamente irreprochables y en los cuales

39 Hoy parece definitivamente aceptado que el Art Déco es algo más que la revisión de obras y objetos derivados de la Exposición de Artes Decorativas e Industriales de 1925, entendiéndose como el conjunto de tendencias estéticas, a veces contrapuestas, que confluyen en un estilo característico durante la sociedad de entreguerras. Estrella de Diego, siguiendo a Applegate, lo resume en los términos que se citan. En DIEGO, E. De. "llustraciones de Penagos. Déco y reminiscencia finisecular». Rev. Goya n. ${ }^{\circ}$ 175-176. Madrid. Julio-octubre, 1983. Págs. 32-39. Ver también Pérez Rojas, J. Art déco... Op. Cit. Págs. 2-20. Y Van de Lemme, A. Art Déco. Madrid. Ágata. 1997. Págs. 2-22. 
no se exigía un especial esfuerzo intelectual e interpretativo. La sexualidad de los cuerpos femeninos era entendida y valorada por una sociedad moderna y cosmopolita, ajena a esa «hipocresía española (...) que gangrena la sangre y la imaginación (...) y no consiente reproducir en LA ESFERA los más característicos lienzos de Federico Beltrán» de la que habla Silvio Lago ${ }^{40}$. Fruto de este éxito se le confió ese mismo año la organización de la Exposición hispano-francesa de Zaragoza. Y el crítico Camille Mauclair publicaba una carta abierta en varias revistas especializadas en los términos siguientes: «...Quiero decirle cómo me ha emocionado todo lo que me ha mostrado. No había tenido una sensación parecida desde hace muchos años. $Y$ a usted le debo haberme devuelto la esperanza (...) Es un maestro y considero que desde mi querido Zuloaga ningún pintor de su envergadura ha aparecido en España...." ${ }^{41}$.

Un año más tarde acude a la Exposición Internacional de Venecia, en la que estuvo representado con veintidós cuadros que ocupaban por completo la quinta sala de la muestra. Allí reafirmará su prestigio y se iniciará su éxito en el ámbito internacional. Entre las obras presentadas volvía a sobresalir la popular Maja Maldita, junto a un Autorretrato con trasunto amoroso al fondo que le fue solicitado por la Galería degli Uffizzi de Florencia (fig. 12). Este hecho no hacía sino confirmar la valoración de Beltrán en una bienal en la que estaban representados entre otros Cezanne, Hodler, Matisse, Signac o Van Gogh.

El impacto de la ciudad de los canales en el pintor se advierte en una serie de obras de escena y ambiente venecianos o con el carnaval como protagonista, realizadas a lo largo de los primeros veinte (Mujeres venecianas, fig. 13). Casualmente coincide con el despertar del interés de Antonio de Hoyos por la ciudad "cuyo misterio mira desde el glauco fondo de sus embrujadas lagunas" y que se refleja en su cuento La máscara veneciana. Venecia era durante los primeros años veinte el símbolo de la decadencia misma, pero al tiempo se había convertido también en la capital artística de una sociedad nobiliaria amante de las nuevas costumbres: el sol, los baños, el culto al cuerpo, la moda..., el déco. El marqués —quintaesencia del nuevo espíritu para Pérez Rojas - comparaba poco antes la pintura de Beltrán con Moreau por «la magnificencia de las concepciones, la elegancia suprema de las arquitecturas, la estética de las agrupaciones...", con Veronés y Tintoretto ${ }^{42}$. Aun pretenciosa, la cita abundaba en las fuentes de inspiración

40 LAGO, S. «Las últimas obras... Op. Cit. S/p.

41 Carta reproducida en Francés, J. Federico... Op. Cit. Pág. 23.

42 Hoyos y VInent, A. Una Impresión... Op. Cit. Págs. 33-37. 


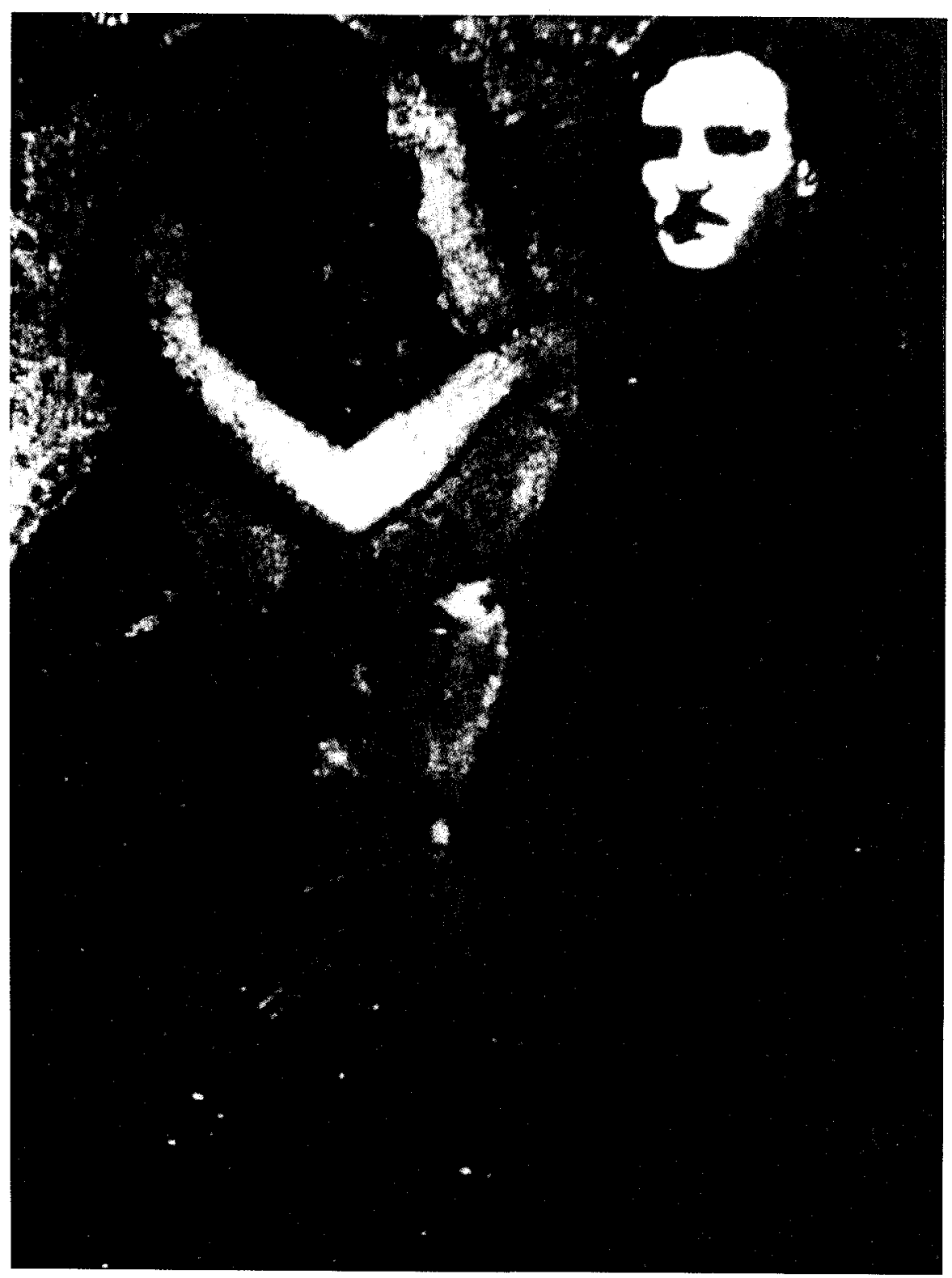

Fig. 12. Autorretrato. 1920. Gallería degli Uffizzi. Florencia. 


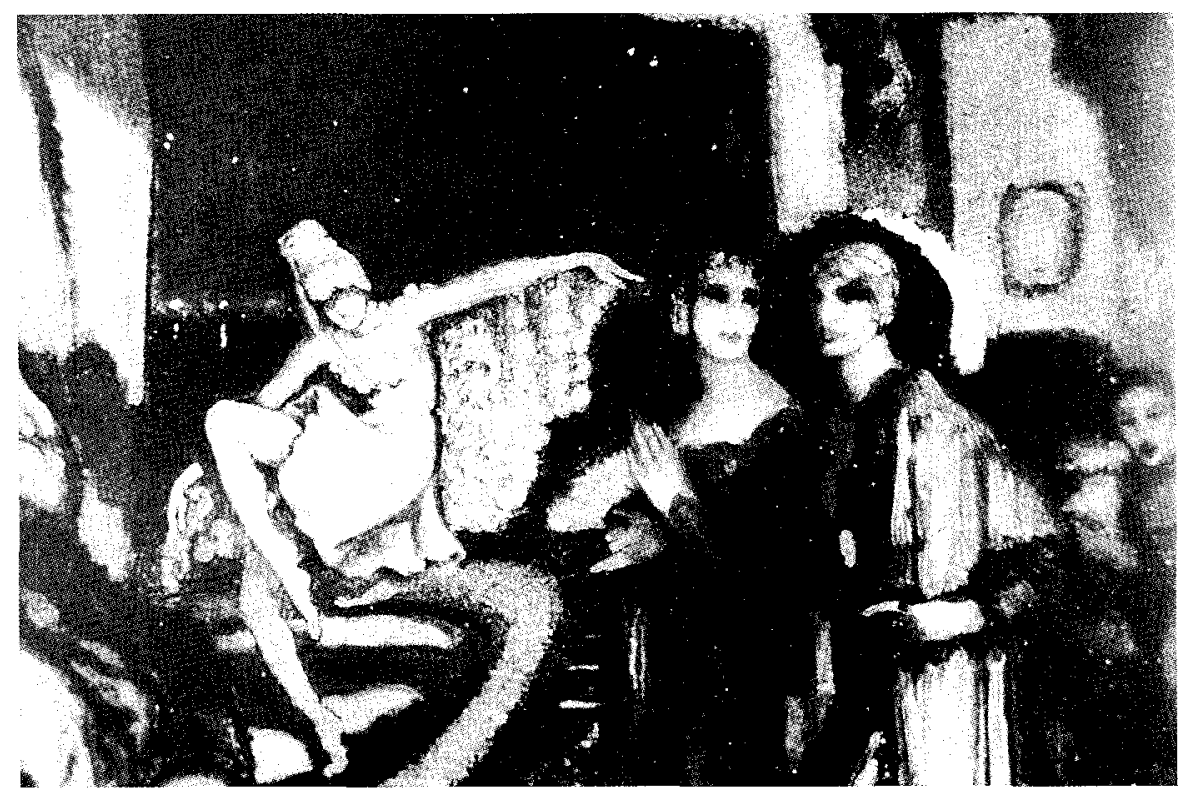

Fig. 13. Mujeres carnavalescas. h. 1920. Museo Art Nouveau y Art Déco. Salamanca.

del hispano-cubano y en una línea creativa muy fértil en el arte español desde principios de siglo: el Simbolismo y el Renacimiento manierista, e incidiendo sobre la exuberancia y sofisticación de sus obras reivindicaba los caracteres del déco. En 1921, los elogios más encendidos volvían a ser de la crítica francesa más acomodada. Mauclair defendía su obra por la «alegría cromática de maestro veneciano y por su romanticismo violento", influenciada por «el drama lírico de la luz» de Monticelli, el «impudor» de Rops, la utilización del «negro whistleriano», la «amargura de Baudelaire», el «paganismo alucinado de Swinburne» o los «métodos creativos de Poe». Conscientemente o no, había puesto el acento sobre las claves del tardosimbolismo en una mezcla de la técnica impresionista más florida, la alegoría más decadente y el erotismo más pagano; «inmenso poema de colores, fiesta para los ojos y una especie de vasta iluminación sensorial y espiritual (...) cuyo interés es ante todo decorativo" ${ }^{43}$. Desde similares posiciones Louis Vauxcelles hablaba de Beltrán como un «obrero espléndido de la pintura», en cuyas composiciones domina «el orden, la claridad, la disciplina, la

43 Mauclair, C. "L'art de Beltrán Massés». En L'ouvre de Federico Beltrán Massés. París. Editions D'art Vizzavona. 1921. S/p. 
voluntad y la razón». Y comparaba su técnica con la de Sorolla y sus «volúmenes, colores y mujeres en jardines con flores" con los de Anglada Camarasa. Lo esencial de su pintura era para Vauxcelles el simbolismo de sus evocaciones: «Las noches de Granada, los gitanos o Salomé», inspirados en la literatura de Lorrain, Baudelaire, Poe y Villiers; en la música de Wagner y en la pintura de Moreau o Leonardo ${ }^{44}$.

Venecia y este tipo de críticas constituyeron una plataforma inmejorable para conseguir el reconocimiento del mundo artístico más académico y hacerse con un nombre en los ambientes internacionales. Por eso, el periodo de entreguerras será de una actividad febril para el pintor. Expone en París, Londres, Nueva York o Los Ángeles; viaja por todo el mundo: Europa, América, India...; y recibe nombramientos y condecoraciones en algunas de las más tradicionales instituciones artísticas y culturales: Invitado de honor de la Sociedad Nacional de Bellas Artes de Francia (1921), miembro de la Real Academia de Bellas Artes de San Fernando (1924), comisario de la Exposición Internacional de Bellas Artes de Burdeos conmemorativa del centenario del fallecimiento de Goya (1928), miembro de honor de la Hispanic Society of América (1939), etc. Paralelamente aparecen las primeras críticas severas, como la del peruano José Carlos Mariategui quien en 1925 calificaba su pintura como «la decadencia de la decadencia» y «propia del gusto banal de una burguesía pingüe y rastacuera» 45 . Sin pretenderlo, demostraba que su fama había llegado también a Hispanoamérica.

El prestigio internacional condicionará notablemente su producción artística posterior, dedicándose a la faceta de retratista casi con exclusividad; tanto de las clases más poderosas (Alfonso XIII, el Sha de Persia, Antonio Rothschild...) como de los artistas del star-system de Hollywood o del Broadway de Ziegfeld (Virginia Heriot, Pola Negri, Valentino...), en un rasgo definitivo de su evolución déco. Santiago Ontañón señala al respecto el carácter casi seriado de estos retratos y el tipo de personajes que desfilaban por el estudio de Beltrán: «Había grandes retratos, a veces verdaderamente enormes, de mujeres bellísimas y famosas: la marquesa de Casa Mauri, la duquesa de Sforza, Madame Nardi, María Barrientos, Lucrecia Bori, Rodolfo Valentino y su mujer, el Karim de Kapurtala, tan guapo que hoy se confundiría con un travestí; Anita Delgado, su madre

\footnotetext{
44 Vauxcelles, L. «Beltrán ef la Peinture Espagnola Contemporaine». En L'ouvre de Federico Beltrán Massés. París. Editions D’art Vizzavona. 1921. S/p.

45 Mariategui, J.C. «El éxito mundano de Beltrán Massés». El artista y su época. Lima. Amauta. 1959. Págs. 82-85.
} 


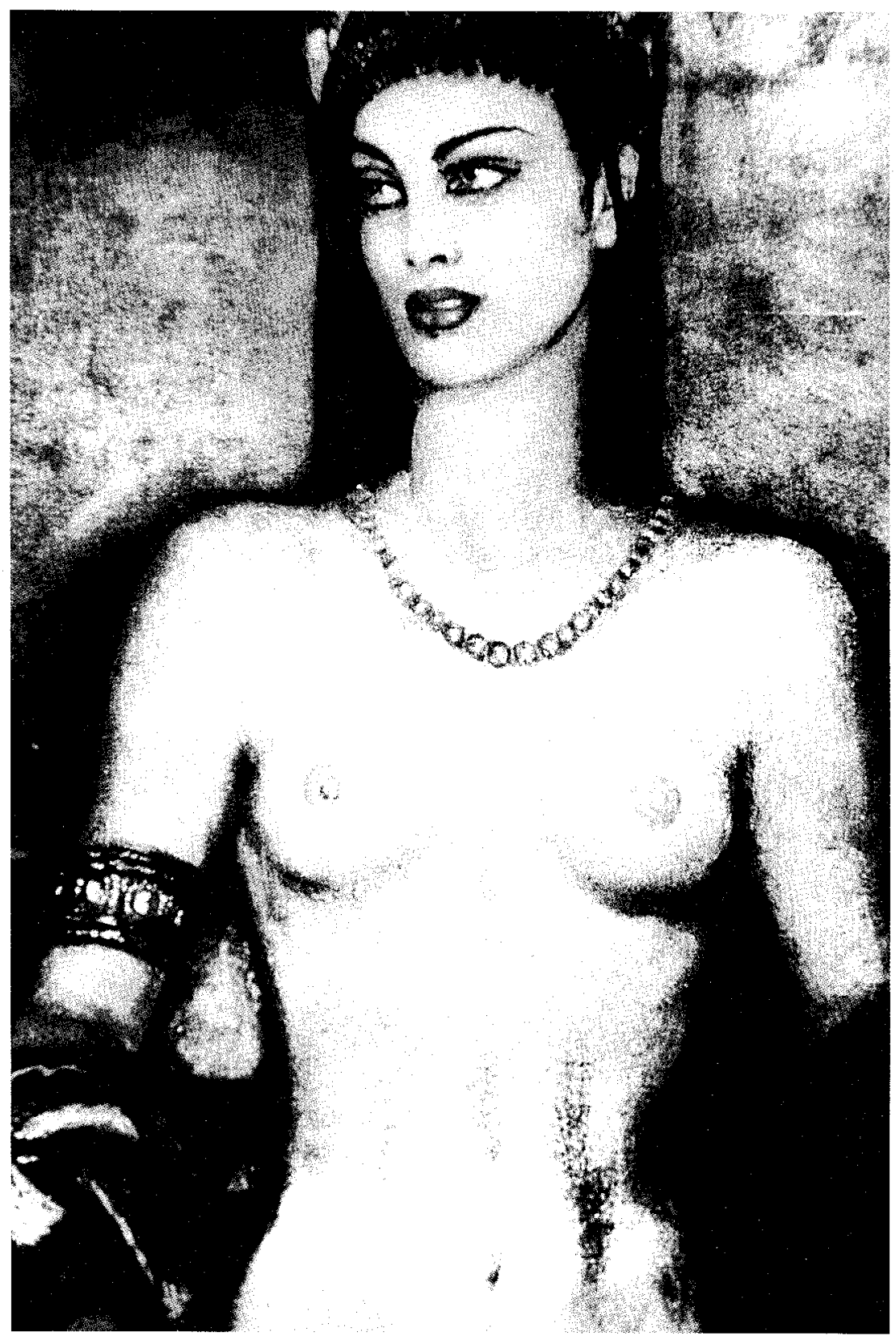

Fig. 14. M.a Antonia de Rochi como Salomé. h. 1922. Museo Art Nouveau y Art Déco. Salamanca. 
(...) Lo curioso era comprobar el asombroso parecido de los retratados; los mismos ojos fosforescentes, las mismas curvas sinuosas e idénticas transparencias de ropajes...». La cita tiene el matiz disconforme del discípulo que luego cultivó los ambientes de vanguardia, pero también la validez de quien, sin favoritismos, reconoce la valía de estas obras a propósito del retrato de Karim de Kapurtala: "Beltrán le hizo un retrato sensacional y otro a Anita, mucho más grande y también muy bueno...» ${ }^{46}$. Por encima de su calidad técnica o de su afectación, el interés de estas obras radica en ser crónica viva de un mundo donde la elegancia se convierte en la razón de ser de una modernidad que adora la velocidad, la danza, el cine o el deporte. Son retratos típicamente déco en su concepción y en un cosmopolitismo capaz de aunar bajo un mismo modelo a la españolísima Paloma Sandoval, la sofisticada Pola Negri o la exótica $\mathrm{M}^{\mathrm{a}}$ Antonia de Rochi caracterizada de Salomé (fig. 14). La «nueva mujer» es el tema referencial del nuevo estilo, como símbolo del progreso de la sociedad futura y de su eterna juventud. El propio pintor lo explicará aludiendo al retrato de la anciana marquesa de Mauri: «Entre pintar a una mujer hermosa como la del cuadro o limitarse a copiar fielmente esta realidad, prefiero lo primero" ${ }^{47}$.

Sus triunfos en el extranjero fueron recogidos también por la prensa española. En 1924 el crítico de arte de La Esfera, Antonio G. de Linares, aún sigue hablando del simbolismo del "pintor de almas; iluminador de las formas con los reflejos del espíritu; alquimista del arte... " ${ }^{48}$. Poco después, para Luis de Galinsoga, redactor de Blanco y Negro, Beltrán en París no podía ser sino un clásico, en la «línea arcaizante e inmóvil» del recuperado Ingres ${ }^{49}$. Se observa, sin embargo, un distanciamiento respecto a sus fuentes de inspiración inicial, coincidiendo con el giro político del marques de Hoyos o el erotismo más desenfrenado de Francés, y significando el declive definitivo de la pintura de Beltrán.

Desde finales de los veinte los retratos irán adquiriendo un carácter más convencional y forzado (Retrato del militar Nicolás de Escoriaza, fig. 15), alternándolos con paisajes de técnica impresionista y fauvista, decorativos y trasnochados. Aun así, conservará su prestigio entre la comunidad artística española y participará en la exposición L'art espagnol contemporaine, celebrada en París en 1936, junto a artistas como Anglada,

46 Ontañon, S. y Moreiro, J.M. Unos pocos... Op. Cit. Págs. 24 y 29.

Ibídem. Pag. 25.

48 Linares, A.G. de: "Beltrán Masses, pintor de almas». Rev. La Esfera, n. ${ }^{\circ}$ 550. Madrid.

49 Galinsoga, L. «Federico Beltrán». Rev. Blanco y Negro. Madrid. 1 de agosto de 1926. 


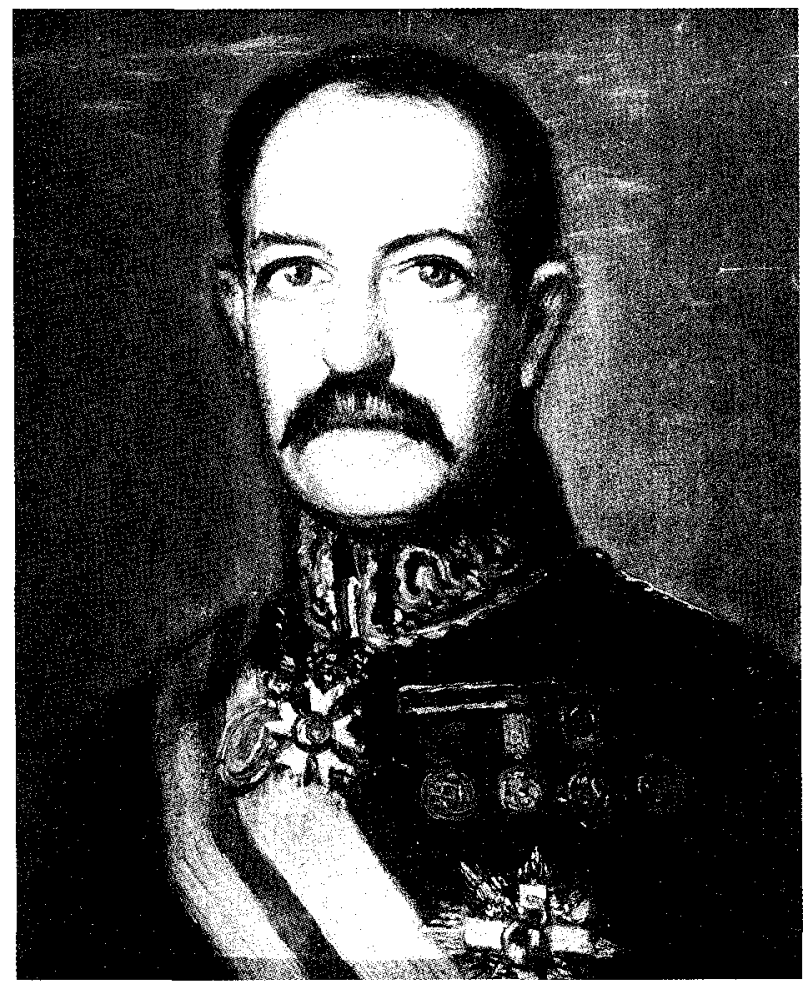

Fig. 15. Retrato del militar Nicolás de Escoriaza. Museo de Zaragoza.

Chicharro, Nonell, Ortiz Echagüe, Pinazo, Sert, Sorolla, Zuloaga o los más vanguardistas Juan Gris, Miró y Picasso.

Pocos años más tarde la carrera de Beltrán sólo interesaba a un grupo de «condesas viejas y príncipes sospechosos», según González-Ruano, quien resume en 1940 su obra parisina: «Aún quedaban en su estudio ejemplos de desnudos bien resueltos, muestras de un soit dissant pintura española, mil veces más estimable que los retratos aristocráticos que hacía ahora a marchas forzadas, cobrando caro y trabajando barato... $\gg 50$.

En 1943 regresa a España gravemente enfermo y de manera definitiva. Ese mismo año expone en el hotel Palace de Madrid y en la galería

50 GonzÁlez-RIJANO, C. «Ficha impresionista de veinte pintores españoles en París (1940-1942)». Rev. Anales de los Museos de Arte de Barcelona. Vol. IV. Barcelona. Ayuntamiento. 1946. Pág. 190. 
Pallarés de Barcelona algunos trabajos de su última etapa francesa. Establecido en el hotel Ritz de la Ciudad Condal, pinta ahora algunas obras de carácter religioso - acordes con la situación política de posguerra-, retratos y cuadros de inspiración literaria en un estilo afectado y cursi. En 1947 y 48 celebra sendas exposiciones en los salones del Ritz que constituyen un anacronismo en la Barcelona que gesta Dau al Set, pero que gustan en los ambientes más oficialistas. El 4 de octubre de 1949 muere en la capital catalana y su cadáver es expuesto en una capilla de honor en la Real Academia de Bellas Artes de San Jorge.

Sus propuestas alegóricas, que beben de las fuentes finiseculares de la fantasía y el sexo, hacen de Beltrán un pintor de símbolos que aúna aspectos cosmopolitas y vernáculos, a través del naturalismo erótico literario y la revisión de lo goyesco. Es también un pintor déco, según la propuesta de Gómez de la Serna de prolongar el efecto estético en la vida cotidiana. Quien mejor que él, «con su americana negra, cintita en el ojal, su pantalón de corte, su aire untuoso de quien acaba de salir de la peluquería de un gran hotel» ${ }^{51}$ representaba al artista dentro y fuera del estudio. El siguiente fragmento, extracto de la novela La vejez de Heliogábalo, escrita por su amigo y mentor Antonio de Hoyos en 1912, condensa buena parte del ideario intelectual del escritor y resume la filosofía estética de Beltrán a través del protagonista, alter-ego del emperador romano admirado por su belleza e inconsciente descripción del pintor: «Poseía el sentido bello del gesto, de la postura (espiritual y material) elegante, de la oportunidad, de la frase feliz. Su sensibilidad afinada, exasperada por una neurosis sabiamente calculada, dábale el horror de la fealdad y la pasión por todo lo estético. Su espíritu sutil sabía, buceando en todas las miserias, hallar algo que es casi siempre inaccesible al vulgo: la belleza del contraste. Amaba todo lo grande, todo lo trágico y lo mismo sentía la belleza en la placidez de un paisaje de égloga o de la magnificación de una marina bravía que en las escenas canallescas de los suburbios. Sus nociones del bien y el mal, nunca fueron claramente definidas, se habían fundido en una noción estética única. «iLa belleza, fuera como fuera, fuera donde fuera!».

51 Ibidem. Pag. 191. 